\title{
Measurement report: Variability in the composition of biogenic volatile organic compounds in a Southeastern US forest and their role in atmospheric reactivity
}

\author{
Deborah F. McGlynn" ${ }^{1}$, Laura E. R. Barry ${ }^{2}$, Manuel T. Lerdau ${ }^{2,3}$, Sally E. Pusede ${ }^{2}$, and Gabriel Isaacman-VanWertz ${ }^{1}$ \\ ${ }^{1}$ Department of Civil and Environmental Engineering, Virginia Tech, Blacksburg, VA 24061, USA \\ ${ }^{2}$ Department of Environmental Sciences, University of Virginia, Charlottesville, VA 22904, USA \\ ${ }^{3}$ Department of Biology, University of Virginia, Charlottesville, VA 22904, USA
}

Correspondence: Deborah F. McGlynn (mcglyndf@vt.edu) and Gabriel Isaacman-VanWertz (ivw@vt.edu)

Received: 17 May 2021 - Discussion started: 20 May 2021

Revised: 27 August 2021 - Accepted: 6 September 2021 - Published: 22 October 2021

\begin{abstract}
Despite the significant contribution of biogenic volatile organic compounds (BVOCs) to organic aerosol formation and ozone production and loss, there are few longterm, year-round, ongoing measurements of their volume mixing ratios and quantification of their impacts on atmospheric reactivity. To address this gap, we present 1 year of hourly measurements of chemically resolved BVOCs between 15 September 2019 and 15 September 2020, collected at a research tower in Central Virginia in a mixed forest representative of ecosystems in the Southeastern US. Mixing ratios of isoprene, isoprene oxidation products, monoterpenes, and sesquiterpenes are described and examined for their impact on the hydroxy radical $(\mathrm{OH})$, ozone, and nitrate reactivity. Mixing ratios of isoprene range from negligible in the winter to typical summertime $24 \mathrm{~h}$ averages of 4-6 ppb, while monoterpenes have more stable mixing ratios in the range of tenths of a part per billion up to $\sim 2 \mathrm{ppb}$ year-round. Sesquiterpenes are typically observed at mixing ratios of $<10 \mathrm{ppt}$, but this represents a lower bound in their abundance. In the growing season, isoprene dominates $\mathrm{OH}$ reactivity but is less important for ozone and nitrate reactivity. Monoterpenes are the most important BVOCs for ozone and nitrate reactivity throughout the year and for $\mathrm{OH}$ reactivity outside of the growing season. To better understand the impact of this compound class on $\mathrm{OH}$, ozone, and nitrate reactivity, the role of individual monoterpenes is examined. Despite the dominant contribution of $\alpha$-pinene to total monoterpene mass, the average reaction rate of the monoterpene mixture with atmospheric oxidants is between $25 \%$ and
\end{abstract}

$30 \%$ faster than $\alpha$-pinene due to the contribution of more reactive but less abundant compounds. A majority of reactivity comes from $\alpha$-pinene and limonene (the most significant low-mixing-ratio, high-reactivity isomer), highlighting the importance of both mixing ratio and structure in assessing atmospheric impacts of emissions.

\section{Introduction}

Biogenic volatile organic compounds (BVOCs) are a dominant source of reactive carbon in the atmosphere, with an estimated $90 \%$ of BVOCs emitted from natural ecosystems (Guenther et al., 1995, 2012). In the presence of nitrogen oxides $\left(\mathrm{NO}_{x} \equiv \mathrm{NO}+\mathrm{NO}_{2}\right)$, BVOCs can react to form tropospheric ozone $\left(\mathrm{O}_{3}\right)$, which has deleterious effects on human health and ecosystems (Lim et al., 2012; Avnery et al., 2011a, b; Kroll and Seinfeld, 2008). These reactions also result in the formation of lower volatility gases and secondary organic aerosol (SOA) (Atkinson and Arey, 2003; Guenther et al., 1995; Kroll and Seinfeld, 2008; Hallquist et al., 1997), which have direct and indirect effects on the radiative balance of the atmosphere (Intergovernmental Panel on Climate Change, 2013). Once emitted, BVOCs react with and destroy $\mathrm{O}_{3}$ or produce $\mathrm{O}_{3}$ through reactions with other oxidants (in particular, the hydroxyl radical) (Wolfe et al., 2011; Kurpius and Goldstein, 2003). The impact of plant emissions on net $\mathrm{O}_{3}$ production versus loss depends on mixing ratios of $\mathrm{NO}_{x}$, as well as the specific chemistry of the BVOCs emitted 
(Trainer et al., 1993; Peake and Sandhu, 1983; Pusede et al., 2014). Changes in environmental conditions, pollution levels, phenology, and ecological succession affect plants and ecosystems in ways that change their BVOC emissions and ozone uptake (Sadiq et al., 2017; Zheng et al., 2017; Faiola et al., 2019; Lerdau et al., 1997).

BVOC emissions consist largely of terpenes, including isoprene $\left(\mathrm{C}_{5} \mathrm{H}_{8}\right)$, monoterpenes $\left(\mathrm{C}_{10} \mathrm{H}_{16}\right)$, sesquiterpenes $\left(\mathrm{C}_{15} \mathrm{H}_{24}\right)$, and diterpenes $\left(\mathrm{C}_{20} \mathrm{H}_{32}\right)$ (Kesselmeier and Staudt, 1999; Laothawornkitkul et al., 2009; Guenther et al., 2012). These compounds vary widely in their reaction rates with atmospheric oxidants, so the impacts of BVOC emissions on regional atmospheric chemistry and composition vary with atmospheric composition and species composition of the dominant vegetation (Geron et al., 2000; Claeys et al., 2004; Lee et al., 2006; Goldstein and Galbally, 2007; Hoffmann et al., 1997; Atkinson et al., 1992). Compounds that are acyclic or cyclic with endocyclic double bonds tend to react faster with oxidants due to the higher substitution of the alkenyl carbons in contrast to exocyclic double bonds, which often have one unsubstituted alkenyl carbon (Hatakeyama et al., 1989). Endocyclic monoterpenes (e.g., myrcene, limonene, and $\Delta^{3}$-carene) and sesquiterpenes (e.g., $\alpha$-humulene and $\beta$ caryophyllene) (Atkinson and Arey, 2003; Matsumoto, 2014) also have a greater aerosol formation potential because $\mathrm{C}-\mathrm{C}$ scission of the double bond is less likely to produce highvolatility fragments (Friedman and Farmer, 2018). Additionally, previous studies that have assessed the reactivity of $\mathrm{OH}$ and $\mathrm{O}_{3}$ have found that higher molecular-weight BVOCs are emitted at lower rates but that they make up an outsize percentage of $\mathrm{OH}$ and $\mathrm{O}_{3}$ reactive loss due to their faster reaction rates (Yee et al., 2018; Holzke et al., 2006; Helmig et al., 2006). Therefore, detailed speciated BVOC data are important for understanding the reactivity and formation of ozone and SOA. Furthermore, long-term and detailed measurements of BVOCs can assist in reducing inaccuracies in modeled BVOC emissions and in understanding their contribution in ozone and SOA formation (Porter et al., 2017).

The chemical complexity of BVOCs presents a challenge in understanding both atmospheric oxidant interactions and SOA production and composition. This problem becomes more complex in a changing climate and, subsequently, with changing ecosystems. For example, emissions have been found to increase during a forest thinning event (Goldstein et al., 2004) and decrease during times of severe drought and elevated $\mathrm{CO}_{2}$ (Holopainen et al., 2018; Demetillo et al., 2019). Additionally, increased herbivory has been shown to increase both total plant emissions and the relative proportion of sesquiterpenes, which in turn affects SOA production and composition (Faiola et al., 2018, 2019). Therefore, understanding oxidant budgets, SOA formation, and future changes to ecosystems and atmospheric composition requires a detailed chemical understanding of BVOCs.

BVOCs have been the subject of a large number of measurements and studies, and an exhaustive overview of avail- able datasets is outside of the scope of this paper. Generally, measurement campaigns make trade-offs between temporal resolution, chemical resolution, and long-term instrument stability. Many campaigns of a few weeks to a few months have provided chemically detailed (i.e., isomer-resolved) measurements of BVOCs with time resolution on the order of hours (Park et al., 2010; Goldstein et al., 2004; Schade and Goldstein, 2003; Schade et al., 1999; Gilman et al., 2009), while longer term (multi-season or multi-year) measurements tend to achieve lower temporal resolution (Holdren et al., 1979; Guenther et al., 1996; Simpson et al., 2012). Some measurements have provided temporal resolution on the order of minutes using direct mass spectrometry (e.g., proton transfer reaction mass spectrometry (Fares et al., 2010; Kalogridis et al., 2014; Ghirardo et al., 2010; Davison et al., 2009; Greenberg et al., 2003), but these instruments are unable to resolve isomers that may differ substantially in their reactivity and physicochemical properties. A few measurement campaigns have collected long-term (many months), temporally resolved (hourly), and chemically detailed (isomerresolved) measurements of a range of BVOCs (Read et al., 2009; Kramer et al., 2015; Panopoulou et al., 2020; Millet et al., 2005; Schade and Goldstein, 2001; Plass-Dülmer et al., 2002; Maria Yanez-Serrano et al., 2018; Hellén et al., 2018), but the number of such campaigns is fairly limited, and very few are currently ongoing. These long-term, temporally and chemically detailed measurements are important for understanding the impacts and behavior of BVOCs on timescales relevant to atmospheric processes, from intra-daily to interannually. Therefore, to further advance understanding of the role of biogenic emissions in reactions of atmospheric oxidants on the timescale of hours to seasons, we present 1 year of temporally and chemically resolved BVOC measurements in a forest canopy that is representative of many ecosystems in the Eastern and Southeastern US, as part of an ongoing measurement site, with measurements planned to continue for the indefinite future. We examine here the temporal and seasonal patterns of BVOCs that drive oxidant reactivity. The specific focus of this work is to understand the extent to which composition of major BVOC classes may vary and how minor but reactive components may drive oxidant chemistry. A major outcome of this work is a detailed characterization of monoterpenes that may allow model descriptions and non-isomer-resolved measurements of this chemical class to more accurately capture its impacts on tropospheric chemistry.

\section{Methods}

\subsection{Instrument location and operation}

In-canopy BVOC volume mixing ratios were measured at the Virginia Forest Research Facility $\left(37.9229^{\circ} \mathrm{N}\right.$, $78.2739^{\circ} \mathrm{W}$ ), located in Fluvanna County, Virginia (McG- 


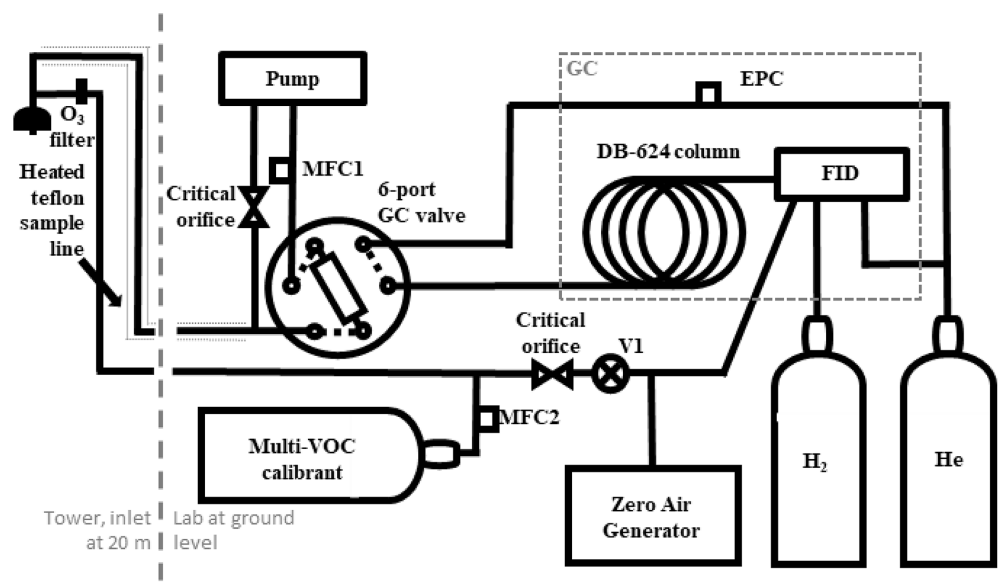

Figure 1. A schematic of the VOC-GC-FID set up at the Virginia Forest Research Lab. MFC, mass flow controller; V1, valve; GC, gas chromatograph; FID, flame ionization detector; EPC, electronic pressure controller; He, helium gas; $\mathrm{H}_{2}$, hydrogen gas. Small, dashed lines around the inlet denote the portion that is heated. The large dashed grey line denotes the indicates that the inlet is within the canopy and the rest of the instrument is in the shed, and the boxed-in dashed grey line denotes the components that are part of the GC.

lynn and Isaacman-VanWertz, 2021). The site is located on the east side of the Blue Ridge Mountains and receives some anthropogenic influence from Charlottesville, VA, and surrounding counties, located $25 \mathrm{~km}$ to the west of the site. Ambient temperature in the winter and spring months of January-April (due to data availability) was $9.6 \pm 9.4^{\circ} \mathrm{C}$ and in the summer and fall months (May-October) was $24.3 \pm$ $7.1^{\circ} \mathrm{C}$ (Fig. S1 in the Supplement). Downwelling shortwave radiation was lower in the winter and spring months $\left(141.4 \pm 214.8 \mathrm{~W} \mathrm{~m}^{-2}\right)$ than the summer and fall months (January-April) on average $\left(235.6 \pm 455.4 \mathrm{~W} \mathrm{~m}^{-2}\right)$ and exhibited lower variability (Fig. S1). The forest canopy consists predominantly of maple, oak, and pine and is approximately $24 \mathrm{~m}$ tall (Chan, 2011). Roughly three-quarters of trees in the forest are species that shed their leaves in the fall and winter months. Tree species found at the site range from being predominantly isoprene emitters, such as oak, to predominantly monoterpene and sesquiterpene emitters, such as conifers (Fuentes et al., 1999). Further information pertaining to tree species at the site can be found in Chan (2011). The site houses a $40 \mathrm{~m}$ meteorological tower, with a climate-controlled, internet-connected lab at the bottom that is supplied by line power, known alternately as "Virginia Forest Research Lab" (VFRL) and "Pace Tower". The measurement period included in this work extends from 15 September 2019 to 15 September 2020, though measurements are ongoing and are anticipated to continue for several years. All results describing seasonality are divided into two separate seasons based on approximate frost dates: the growing season (May-October) and non-growing season (NovemberApril).

Figure 1 depicts the sampling and instrumentation configuration for the automated gas chromatograph-flame ionization (GC-FID) detector used to quantify BVOC volume mixing ratios (the VOC-GC-FID). Air is pulled from midcanopy ( $\sim 20 \mathrm{~m}$ above ground level) at $1400 \mathrm{sccm}$ through a $1 / 8$ in. i.d. Teflon tube in an insulated waterproof sheath held at $45^{\circ} \mathrm{C}$. The residence time of an air sample in the inlet is about $8 \mathrm{~s}$. Ozone is removed from the sample using a sodium-thiosulfate-infused quartz fiber filter (Pollmann et al., 2005) at the front of the inlet. Efficacy of the ozone scrubber was empirically tested by measuring removal over a multi-week exposure to ozone concentrations several times higher than ambient levels. Efficacy was confirmed following deployment by verifying ozone removal of removed filters. A subsample of $\sim 70 \mathrm{sccm}$ is concentrated onto a multibed adsorbent trap composed of (in order of inlet to outlet) $10 \mathrm{mg}$ of Tenax TA, $20 \mathrm{mg}$ of Carbopack X, and $20 \mathrm{mg}$ of Carbopack B, with $15 \mathrm{mg}$ of glass beads between each layer and at the inlet (from Sigma-Aldrich); prior work (Gentner et al., 2012) used a trap composition and analytical system similar to this instrument to sample compounds between $C_{5}$ and $\mathrm{C}_{14}$. A custom LabVIEW program (National Instruments) operates the instrument for automated sample collection and analysis, with the sample collected for $54.5 \mathrm{~min}$ of each hour (total sample volume: $3.8 \mathrm{~L}$ ). Following sample collection, the trap is thermally desorbed under a helium backflush at $140 \pm 10^{\circ} \mathrm{C}$ for $5.5 \mathrm{~min}$, transferring analytes through a heated 6-port valve $\left(150^{\circ} \mathrm{C}\right)$ to the head of the gas chromatography column in a GC oven (Agilent 7890B) with a helium flow rate of $5.5 \mathrm{sccm}$. GC analysis begins at the end of thermal desorption and proceeds throughout the subsequent sample collection, enabling hourly sample collection and analysis. Analytes are separated using a mid-polarity GC column (Rtx-624, $60 \mathrm{~m} \times 0.32 \mathrm{~mm} \times 1.8 \mu \mathrm{m}$, Restek Inc.) and detected by a flame ionization detector (FID). Sample flow is measured by a mass flow controller (MFC1 in Fig. 1, Alicat Scientific), and GC flow is controlled by an electronic 

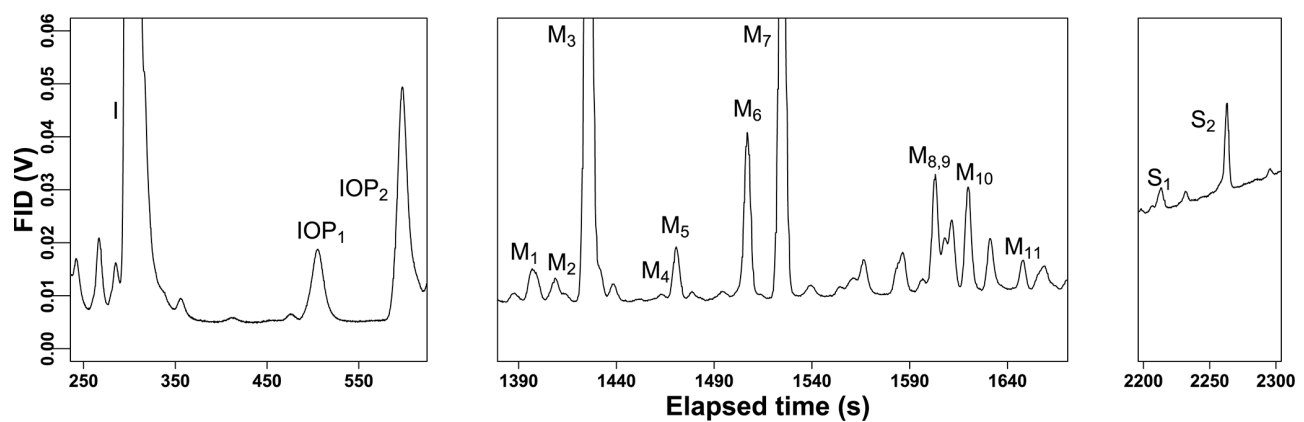

Figure 2. A typical GC chromatogram of sampled ambient air collected at the site. The compounds identified on the figure show the range of species found by the instrumental methods. These include isoprene (I), isoprene oxidation products (IOP), monoterpenes (M), and sesquiterpenes (S). Unlabeled peaks were not identified to be terpenes or isoprene oxidation products and are, in most cases, identifiable as belonging to a different compound class.

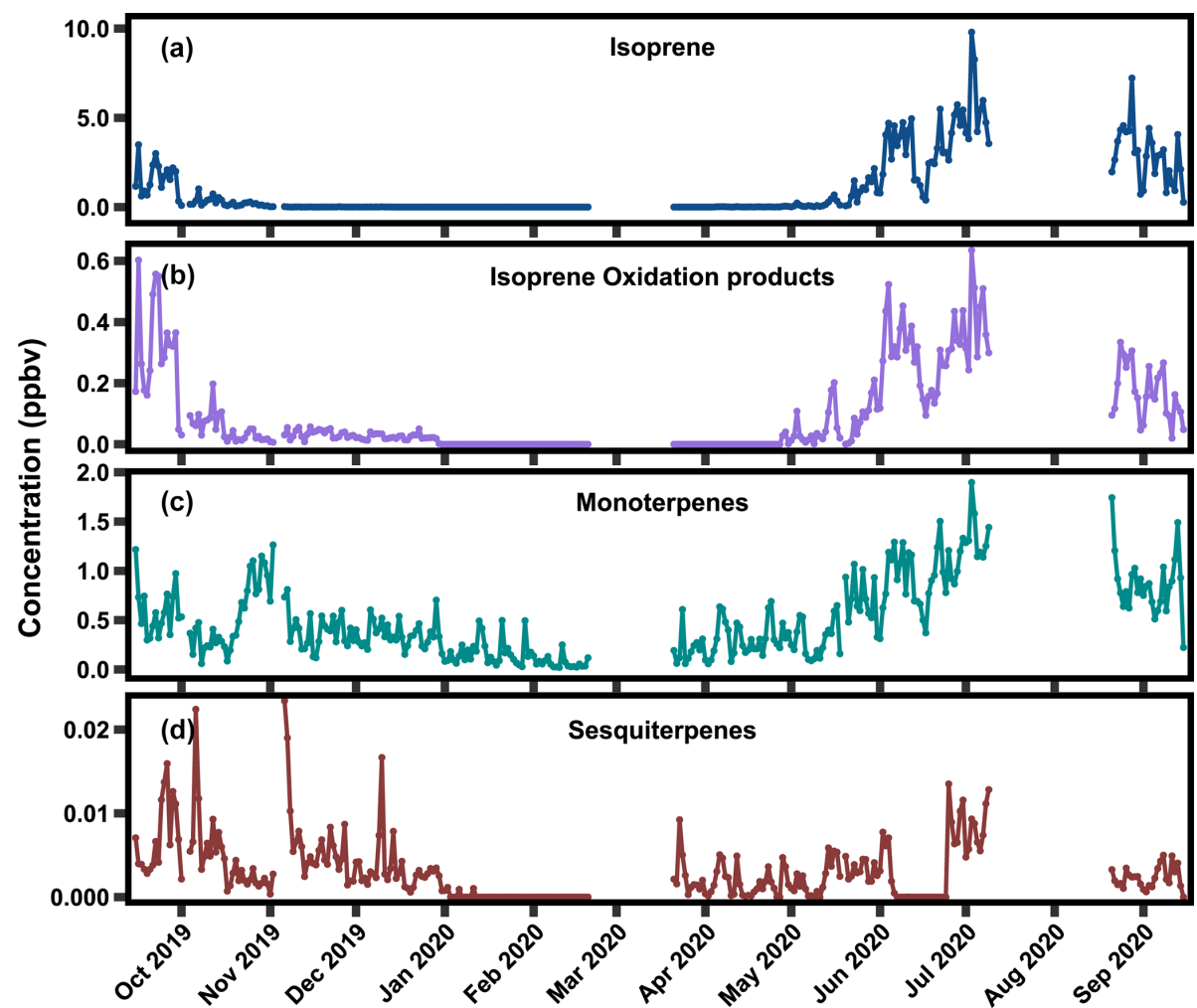

Figure 3. The $24 \mathrm{~h}$ average concentrations of (a) isoprene, (b) isoprene oxidation products (methyl vinyl ketone and methacrolein), (c) sum of monoterpenes, and (d) sum of sesquiterpenes between 15 September 2019 and 15 September 2020.

pressure controller (EPC in Fig. 1) on board the GC. Ultrapure hydrogen and helium are provided from compressed gas cylinders (5.0 grade, AirGas) as FID fuel gas $\left(\mathrm{H}_{2}\right)$, FID makeup gas (He), and GC carrier gas (He). Air for the FID is generated on-site at $30 \mathrm{psig}$ with a zero-air generator (Series 7000, Environics, Inc.).

A major advantage of deploying a GC-FID in a field setting is the limited required maintenance. The most frequent maintenance required by the system is the replacement of ozone filters every 4-6 weeks. The system also requires hydrogen and helium gas tanks, which last for roughly 68 months (though the former could be generated on-site). GC components (traps, columns) require little to no replacement over the time period reported here under normal operation. The oilless vacuum pump used to pull samples suffers somewhat from constant use and overheating in the warmest months of the year and therefore had to be replaced after $\sim 12$ months. 

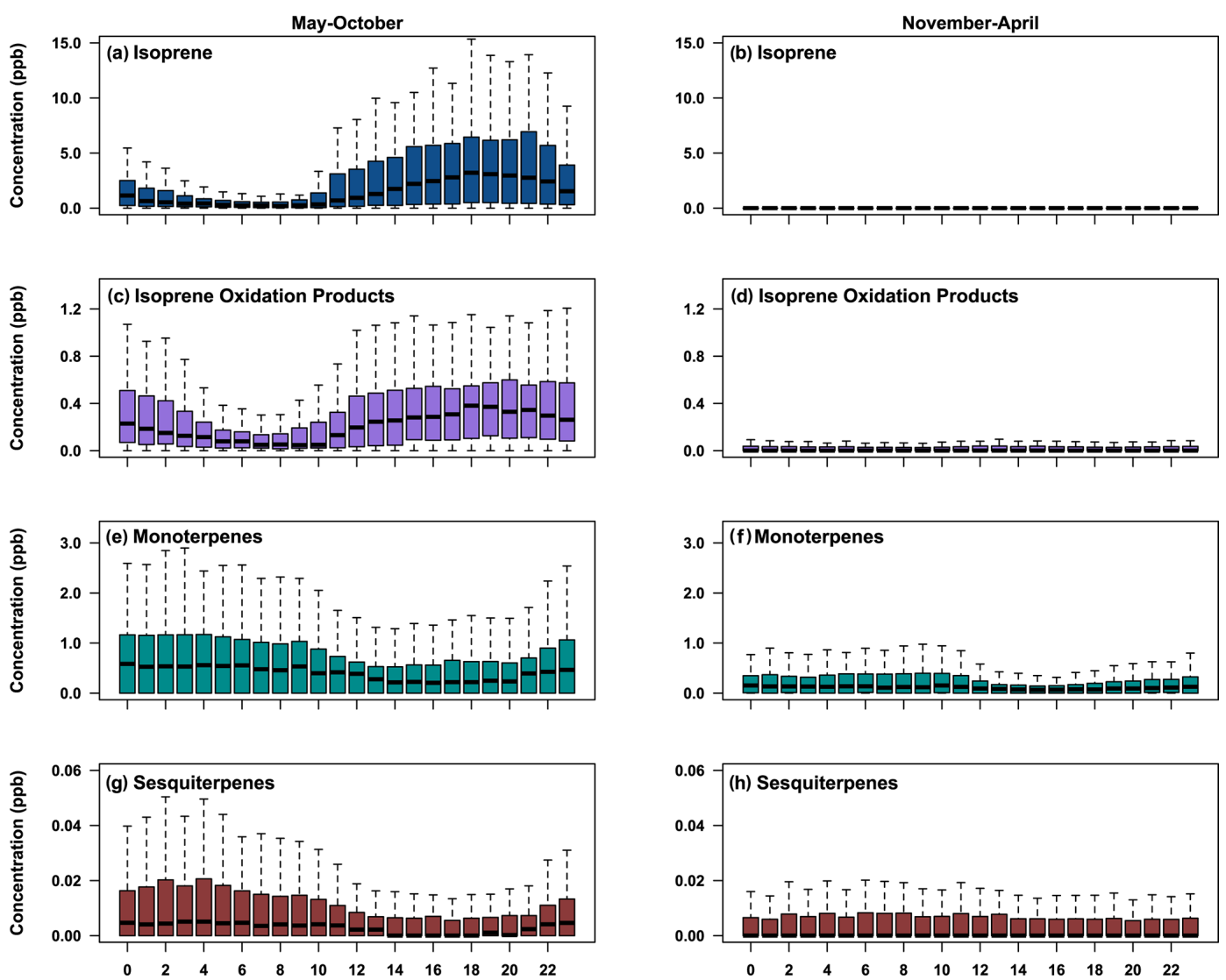

Figure 4. Binned hourly boxplots for the four BVOC classes, divided into the growing season, May-October, and the non-growing season, November-April. Classes shown are (a-b) isoprene, (c-d) isoprene oxidation products, (e-f) monoterpenes, and (g-h) sesquiterpenes. The plots show the median value as a horizontal line, and the bottom and top of each box indicate the 25th and 75th percentiles, while the whiskers represent 1.5 times the interquartile range. Each box represents the data for each hour of the day.

\subsection{Calibration and compound identification}

For calibration, the sample inlet is overblown with $\sim$ $1400 \mathrm{sccm}$ zero air from a zero-air generator, optionally mixed with a multi-component calibrant (Apel-Riemer Environmental Inc.) at one of four different flows (generating four different mixing ratios of calibrant mixtures). A calibration sample occurs each seventh hour, rotating between zero air only, a calibrant at a fixed "tracking" mixing ratio, and a calibrant at one of three other mixing ratios. The composition and pure volume mixing ratio of the multi-component calibrant are provided in Table S1 (in brief: 40.3 ppb isoprene, 4.35-17.60 ppb monoterpenes and sesquiterpenes) and diluted into zero air at flows of $10,25,50$, and $100 \mathrm{sccm}$ to generate dilutions of approximately 140, 60,30, and 15 times respectively. Estimated limits of detection for isoprene, isoprene oxidation products, monoterpenes, and sesquiterpenes are $20,4.3,2.2$, and $2.7 \mathrm{ppt}$, respectively, estimated as the mixing ratio that would yield a chromatographic peak with a height three times the standard deviation of the noise in the chromatographic baseline. Mixing ratios reported above these levels have an estimated uncertainty of $15 \%$, pri- marily driven by uncertainty in chromatographic integration (Isaacman-VanWertz et al., 2017). In most cases, mixing ratios calculated below these values are either reported as LOD (in cases when peaks were too small to be integrated) or reported as calculated but can be considered to have substantial error.

While an FID provides nearly universal quantification of analytes as a function of their carbon content (Scanlon and Willis, 1985; Faiola et al., 2012), it does not provide any chemical resolution. To identify analytes in the samples, a mass spectrometer (MS, Agilent 5977) was deployed in October 2019 and September 2020 in parallel with the FID. Retention times of analytes detected by the two detectors were aligned using the retention time of known analytes (e.g., calibrants). Analytes were identified by mass spectral matching with the 2011 NIST MS Library and reported retention indices (NIST Chemical Kinetics Database, 2020). All analytes reported in this work matched the identified compound within the range of reported retention indices and with a cosine similarity of at least 0.85 . This parameter is the preferred spectral comparison method of the widely used NIST mass spectral library search program, and previous work has 


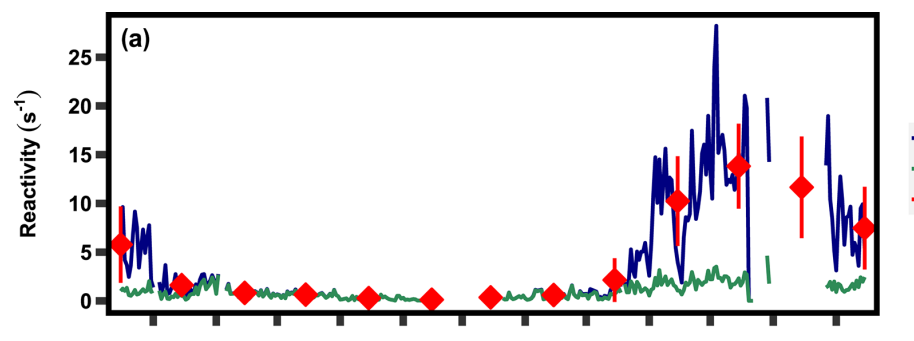

$$
\begin{aligned}
& \text { - All Terpenes } \\
& \text { - Monoterpenes } \\
& \text { - Monthly Mean Reactivity }
\end{aligned}
$$

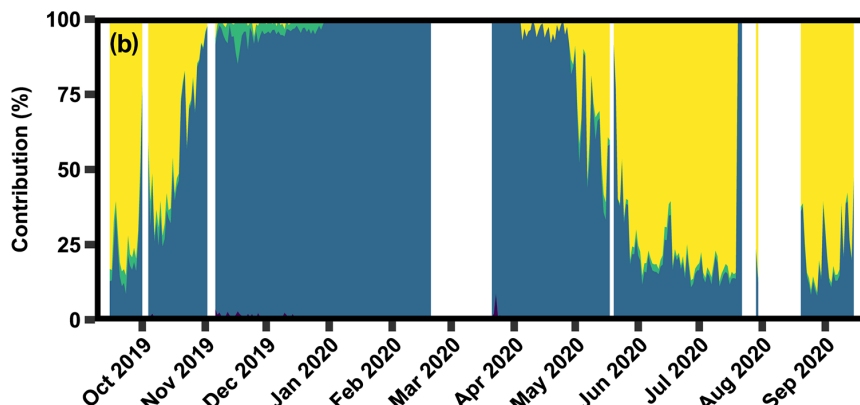

Isoprene

MVK + MACR

Monoterpenes

Sesquiterpenes

Figure 5. (a) Time series of $24 \mathrm{~h}$ averaged calculated $\mathrm{OH}$ reactivity of all measured terpene classes and the monoterpene class, as well as the monthly mean of calculated $\mathrm{OH}$ reactivity. (b) Relative contribution of each of the BVOC classes to OH reactivity.

shown that a threshold of 0.85 or greater indicates a high probability of correct identification (Worton et al., 2017; Stein and Scott, 1994). Data were analyzed using the freely available TERN software packaged (Isaacman-VanWertz et al., 2017) within the Igor Pro 8 programming environment (Wavemetrics, Inc.).

\subsection{Atmospheric oxidant reactivity and reaction rate calculations}

Reactivity of an individual BVOC and/or a BVOC class to the hydroxyl radical (OHR), ozone $\left(\mathrm{O}_{3} \mathrm{R}\right)$, and nitrate $\left(\mathrm{NO}_{3} \mathrm{R}\right)$ is calculated as the sum of the products of the mixing ratio and oxidation reaction rate of each $\mathrm{BVOC}, i$ :

$\mathrm{O}_{x} \mathrm{R}_{\mathrm{tot}}\left(\mathrm{s}^{-1}\right)=\sum\left(k_{\mathrm{O}_{x}+\mathrm{BVOC}_{i}}\left[\mathrm{BVOC}_{i}\right]\right)$.

Published rate constants (units: $\mathrm{cm}^{3}$ molec. ${ }^{-1} \mathrm{~s}^{-1}$ ) at $298 \mathrm{k}$ were used where available (Atkinson et al., 2006; Pfrang et al., 2006; Atkinson et al., 1990; Kerdouci et al., 2010; Pinto et al., 2007; Atkinson and Arey, 2003; Corchnoy and Atkinson, 1990; Shu and Atkinson, 1994; King et al., 1999; Pratt et al., 2012; US Environmental Protection Agency, 2012) and were otherwise calculated from the Kwok and Atkinson structure activity relationships, as implemented by the Estimation Program Interface provided by the US Environmental Protection Agency (Kwok and Atkinson, 1995; US Environmental Protection Agency, 2012; King et al., 1999). Rate constants calculated using structure activity relationships are estimated to be within a factor of $\sim 2$ of measured rate constants (King et al., 1999). However, uncertainty of estimated rate constants is not expected to significantly impact calculated reactivity as compounds with the largest contribution to atmospheric reactivity have measured rate constants.

\section{Results and discussion}

\subsection{Temporal trends in BVOC ratios}

Observed and quantified BVOCs include isoprene, two isoprene oxidation products, methyl vinyl ketone and methacrolein, 11 monoterpene species, and two sesquiterpene species (McGlynn and Isaacman-VanWertz, 2021). Due to the nature of the sample collection, diterpenes and many oxygenated species other than MVK and MACR are poorly captured. Oxygenated species either have volatilities that are too high for efficient trapping (e.g., methanol) or are removed by the ozone filter (e.g., nopinone). Many of the small, oxygenated compounds that might be expected at this site at moderately high abundance (e.g., methanol, acetone) have low reaction rate constants that imply they likely contribute only minutely to $\mathrm{OHR}$ and $\mathrm{NO}_{3} \mathrm{R}$ and not at all to $\mathrm{O}_{3} \mathrm{R}$. The exception may be acetaldehyde, which previous work has been shown to contribute non-negligibly to reactivity (Hunter et al., 2017) but is too volatile to be trapped by the instrument used in this work. A sample chromatogram is shown in Fig. 2. The detected monoterpene species include $\alpha$-pinene, $\beta$-pinene, $\beta$-phellandrene, camphene, limonene, tricyclene, $\alpha$-fenchene, thujene, cymene, sabinene, and $\gamma$-terpinene (Table 1). The sesquiterpene species regularly detected include $\alpha$-cedrene and $\beta$-cedrene, but these are generally present at very low mixing ratios. Consequently, we expect that not all sesquiterpenes are captured by this instrument and caution 
Table 1. Compound identities on an example chromatogram and associated rate constants $\left(\mathrm{cm}^{3}\right.$ molec. $\left.{ }^{-1} \mathrm{~s}^{-1}\right)$ for OH, ozone, and nitrate.

\begin{tabular}{llrrrr}
\hline Compound & Symbol & Retention time (s) & $k_{\mathrm{OH}+\mathrm{BVOC}_{i}}$ & $k_{\mathrm{O}_{3}+\mathrm{BVOC}_{i}}$ & $k_{\mathrm{NO}_{3}+\mathrm{BVOC}_{i}}$ \\
\hline Isoprene & $\mathrm{I}$ & 308 & $1.01 \times 10^{-10, \mathrm{a}}$ & $1.27 \times 10^{-17, \mathrm{a}}$ & $7.00 \times 10^{-13, \mathrm{a}}$ \\
Methyl vinyl ketone & $\mathrm{IOP}_{1}$ & 504 & $5.60 \times 10^{-12, \mathrm{~b}}$ & $1.00 \times 10^{-20, \mathrm{c}}$ & $4.70 \times 10^{-15, \mathrm{~d}}$ \\
Methacrolein & $\mathrm{IOP}_{2}$ & 597 & $5.00 \times 10^{-11, \mathrm{~b}}$ & $1.00 \times 10^{-20, \mathrm{c}}$ & $9.60 \times 10^{-16, \mathrm{~d}}$ \\
Thujene & $\mathrm{M}_{1}$ & 1397 & $7.10 \times 10^{-11, \mathrm{e}}$ & $6.20 \times 10^{-17, \mathrm{e}}$ & $5.5 \times 10^{-12, \mathrm{f}}$ \\
Tricyclene & $\mathrm{M}_{2}$ & 1409 & $2.66 \times 10^{-12, \mathrm{~g}}$ & 0 & 0 \\
$\alpha$-pinene & $\mathrm{M}_{3}$ & 1423 & $5.37 \times 10^{-11, \mathrm{a}}$ & $9.00 \times 10^{-17, \mathrm{a}}$ & $6.20 \times 10^{-12, \mathrm{k}}$ \\
$\alpha$-fenchene & $\mathrm{M}_{4}$ & 1463 & $5.70 \times 10^{-11, \mathrm{c}}$ & $1.20 \times 10^{-17, \mathrm{c}}$ & $8.95 \times 10^{-13, \mathrm{c}}$ \\
camphene & $\mathrm{M}_{5}$ & 1470 & $5.33 \times 10^{-11, \mathrm{~g}}$ & $9.00 \times 10^{-19, \mathrm{e}}$ & $6.20 \times 10^{-12, \mathrm{e}}$ \\
sabinene & $\mathrm{M}_{6}$ & 1507 & $1.17 \times 10^{-10, \mathrm{~g}}$ & $8.30 \times 10^{-17, \mathrm{~g}}$ & $1.00 \times 10^{-11, \mathrm{k}}$ \\
$\beta$-pinene & $\mathrm{M}_{7}$ & 1522 & $7.89 \times 10^{-11, \mathrm{~g}}$ & $2.10 \times 10^{-17, \mathrm{~g}}$ & $2.50 \times 10^{-12, \mathrm{k}}$ \\
cymene & $\mathrm{M}_{8}$ & 1608 & $1.51 \times 10^{-11, \mathrm{~h}}$ & 0 & $9.90 \times 10^{-16, \mathrm{~h}}$ \\
limonene & $\mathrm{M}_{9}$ & 1600 & $1.64 \times 10^{-10, \mathrm{~g}}$ & $6.40 \times 10^{-16, \mathrm{~g}}$ & $1.22 \times 10^{-11, \mathrm{k}}$ \\
$\beta$-phellandrene & $\mathrm{M}_{10}$ & 1620 & $1.68 \times 10^{-10, \mathrm{~g}}$ & $1.80 \times 10^{-16, \mathrm{~g}}$ & $7.96 \times 10^{-12, \mathrm{k}}$ \\
$\gamma$-terpinene & $\mathrm{M}_{11}$ & 1648 & $1.77 \times 10^{-10, \mathrm{~g}}$ & $1.40 \times 10^{-16, \mathrm{~g}}$ & $2.90 \times 10^{-11, \mathrm{k}}$ \\
$\alpha$-cedrene & $\mathrm{S}_{1}$ & 2257 & $6.70 \times 10^{-11, \mathrm{~g}}$ & $2.78 \times 10^{-17, \mathrm{i}}$ & $8.20 \times 10^{-12, \mathrm{j}}$ \\
$\beta$-cedrene & $\mathrm{S}_{2}$ & 2279 & $6.24 \times 10^{-11, \mathrm{i}}$ & $1.20 \times 10^{-17, \mathrm{i}}$ & $3.55 \times 10^{-13, \mathrm{j}}$ \\
\hline
\end{tabular}

${ }^{a}$ Atkinson et al. (2006). ${ }^{b}$ Paulot et al. (2009). ${ }^{c}$ Atkinson et al. (1990). ${ }^{\mathrm{d}}$ Kerdouci et al. (2010). ${ }^{\mathrm{e}}$ Pinto et al. (2007). ${ }^{\mathrm{f}}$ Pfrang et al. (2006).

${ }^{\mathrm{g}}$ Atkinson and Arey (2003). ${ }^{\mathrm{h}}$ Corchnoy and Atkinson (1990). ${ }^{\mathrm{i}}$ Shu and Atkinson (1994). ${ }^{\mathrm{j}}$ Estimated using King et al. (1999). ${ }^{\mathrm{k}}$ U.S

Environmental Protection Agency (2012).

Table 2. Average and interquartile range of mixing ratio, $\mathrm{OH}(\mathrm{OHR})$, ozone $\left(\mathrm{O}_{3} \mathrm{R}\right)$, and nitrate $\left(\mathrm{NO}_{3} \mathrm{R}\right)$ reactivities in the growing and non-growing seasons.

\begin{tabular}{lcccc}
\hline & \multicolumn{4}{c}{ Growing season average } \\
\cline { 2 - 5 } & Mixing ratio $(\mathrm{ppb})$ & $\mathrm{OHR}\left(\mathrm{s}^{-1}\right)$ & $\mathrm{O}_{3} \mathrm{R}\left(\times 10^{-6} \mathrm{~s}^{-1}\right)$ & $\mathrm{NO}_{3} \mathrm{R}\left(\mathrm{s}^{-1}\right)$ \\
\hline Isoprene & $2.13 \pm 2.99$ & $5.38 \pm 7.55$ & $0.76 \pm 1.07$ & $0.04 \pm 0.05$ \\
MVK + MACR & $0.27 \pm 0.40$ & $0.15 \pm 0.23$ & $0.00 \pm 0.00$ & $0.00 \pm 0.00$ \\
Monoterpenes & $0.74 \pm 0.72$ & $1.37 \pm 1.33$ & $2.38 \pm 2.41$ & $0.10 \pm 0.10$ \\
Sesquiterpenes & $0.01 \pm 0.01$ & $0.01 \pm 0.01$ & $0.00 \pm 0.00$ & $0.00 \pm 0.00$ \\
\hline & & Non-growing season average & \\
\cline { 2 - 5 } & Mixing ratio $(\mathrm{ppb})$ & OHR $\left(\mathrm{s}^{-1}\right)$ & $\mathrm{O}_{3} \mathrm{R}\left(\times 10^{-6} \mathrm{~s}^{-1}\right)$ & $\mathrm{NO}_{3} \mathrm{R} \mathrm{s}^{-1}$ \\
\hline Isoprene & $\mathrm{LOD}$ & - & - & - \\
MVK + MACR & $0.02 \pm 0.03$ & $0.01 \pm 0.02$ & $0.00 \pm 0.00$ & $0.00 \pm 0.00$ \\
Monoterpenes & $0.27 \pm 0.28$ & $0.47 \pm 0.50$ & $0.77 \pm 0.79$ & $0.04 \pm 0.04$ \\
Sesquiterpenes & $0.01 \pm 0.01$ & $0.00 \pm 0.01$ & $0.00 \pm 0.00$ & $0.00 \pm 0.00$ \\
\hline
\end{tabular}

that all reported mixing ratios of sesquiterpenes represent lower bounds.

Daily $24 \mathrm{~h}$ averaged mixing ratios of each BVOC class for the measurement period are shown in Fig. 3. Periods with gaps are due to instrument issues, and periods reported as zero are below the limit of detection (LOD). Many species approached the LOD in the fall and winter months due to low temperatures and decreased incoming shortwave radiation as compared to the warmest months of the year (Fig. S1). Isoprene and its oxidation products (Figs. 3a-b) were near or below detection limits from mid-October to late October through early May. Both classes reached their seasonal peak in late July, with an average \pm interquartile range of hourly isoprene mixing ratio in the growing season of $2.13 \pm 2.99 \mathrm{ppb}$, and near levels of detection in the non-growing season; uncertainties here and throughout represent the interquartile range about the mean. The average mixing ratio of summed isoprene oxidation products was $0.27( \pm 0.40) \mathrm{ppb}$ in the growing season and $0.02( \pm 0.03) \mathrm{ppb}$ in the non-growing season. Interestingly, the ratio of isoprene oxidation products to isoprene is variable over the course of the measurement campaign. In addition to differences in their oxidation rates, these differences may be due in part to anthropogenic emissions, both through the influence of $\mathrm{NO}_{x}$ on isoprene oxidation pathways and the direct emission of MVK and MACR from vehicles (Biesen- 


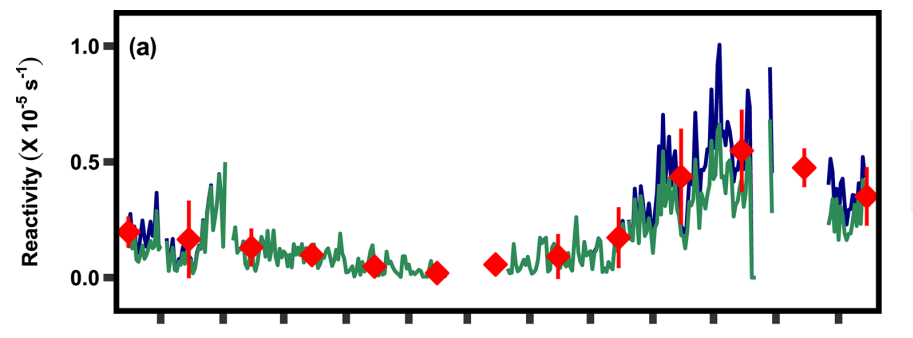

$$
\begin{aligned}
& \text { - All Terpenes } \\
& \text { - Monoterpenes } \\
& \text { - Monthly Mean Reactivity }
\end{aligned}
$$

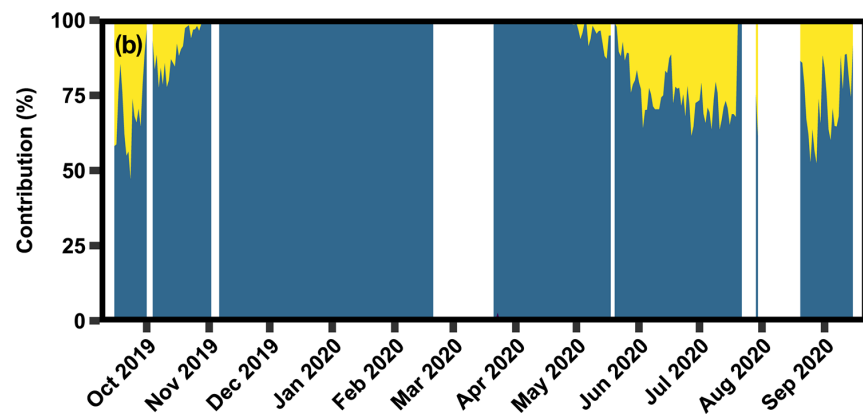

Isoprene

MVK + MACR

Monoterpenes

Sesquiterpenes

Figure 6. (a) Time series of $24 \mathrm{~h}$ averaged calculated ozone reactivity of all terpene classes and the monoterpene class, as well as the monthly mean of calculated ozone reactivity. (b) Relative contribution of each of the BVOC classes to ozone reactivity.

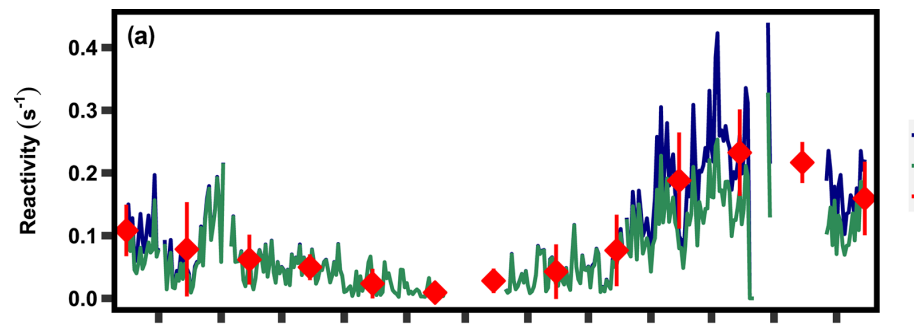

$$
\begin{aligned}
& \text { - All Terpenes } \\
& \text { - Monoterpenes } \\
& \text { - Monthly Mean Reactivity }
\end{aligned}
$$

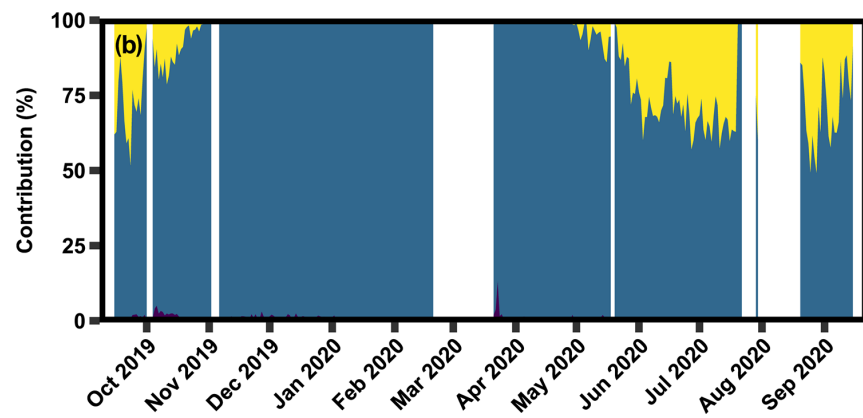

Isoprene

MVK + MACR

Monoterpenes

Sesquiterpenes

Figure 7. (a) Time series of $24 \mathrm{~h}$ averaged calculated nitrate reactivity of all terpene classes and the monoterpene class, as well as the monthly mean of calculated nitrate reactivity. (b) Relative contribution of each of the BVOC classes to nitrate reactivity.

thal and Shepson, 1997; Ling et al., 2019). The average mixing ratio of summed monoterpenes in the growing season is $0.74( \pm 0.72) \mathrm{ppb}$ and $0.27( \pm 0.28) \mathrm{ppb}$ in the non-growing season (Fig. 3c). Monoterpenes exhibit a similar high period during the growing season but are present throughout the non-growing season as well. The average of summer sesquiterpene mixing ratios in the growing season was $0.01( \pm 0.01) \mathrm{ppb}$ and $0.01( \pm 0.01) \mathrm{ppb}$ in the non-growing season. Sesquiterpenes, much like monoterpenes, are detected in both the growing and non-growing season. Average mixing ratios of all classes for each season are provided in Table 2.

Diurnal trends in mixing ratios during the growing season (May-October) and non-growing season (November-April) are shown in Fig. 4 for isoprene, summed isoprene oxidation products, summed monoterpenes, and summed sesquiterpenes. All terpene classes exhibited the highest mixing ratios in the growing season (May-October), when temperature and incoming shortwave radiation were highest (Fig. S1). Isoprene and isoprene oxidation products peak in late af- 
ternoon hours, as expected due to the light dependence of isoprene (Guenther, 1997; Zimmerman, 1979; Lamb et al., 1987). Isoprene and oxidation product mixing ratios were typically below the limits of detection in the non-growing season, with little clear diurnal pattern. In contrast to isoprene, summed monoterpenes exhibit peak values in the evening hours, which is consistent with previously reported findings (Panopoulou et al., 2020; Davison et al., 2009). Evening peak values were higher in the growing season than in the non-growing season. Additionally, daytime lows lasted for longer periods of time in the growing season than in the non-growing season due to longer daylight hours driving more photolytic reactions with the $\mathrm{OH}$ radical and shorter lasting nighttime boundary layers (Davison et al., 2009). Hourly monoterpene mixing ratios ranged between 0.10 and $2.94 \mathrm{ppb}$ throughout the year, with the lowest values occurring in the non-growing season (Fig. 3b).

Sesquiterpene mixing ratios also exhibited peak diurnal mixing ratios in the evening in the growing season. Summed mixing ratios of sesquiterpenes (Fig. $3 g$ and h) include only two species and so represent a lower bound of possible total sesquiterpene mixing ratios. However, the limit of detection for sesquiterpenes is estimated as $2.7 \mathrm{ppt}$, so other sesquiterpenes are unlikely to be present at mixing ratios significantly higher than this. Measured sesquiterpenes therefore provide some insight into the total mixing ratios of sesquiterpenes. Mean sesquiterpene (i.e., sum of $\alpha$ - and $\beta$-cedrene) values were around $0.01( \pm 0.01) \mathrm{ppb}$ in the growing season and exhibited similar diurnal variability to monoterpenes. Outside the growing season, the mean sesquiterpene mixing ratio was $0.01( \pm 0.01) \mathrm{ppb}$, with little discernable diurnal variability.

\subsection{Calculated reactivity with atmospheric oxidants}

\subsubsection{Calculated $\mathrm{OH}$ reactivity}

Calculated $\mathrm{OH}$ reactivity of total observed terpenes varies seasonally, with a $24 \mathrm{~h}$ average summertime peak of $\sim 27 \mathrm{~s}^{-1}$ and growing season average of $8.48( \pm 10.68) \mathrm{s}^{-1}$ driven by isoprene (Fig. 5a). Comparatively, the non-growing season $\mathrm{OH}$ reactivity average was $0.99( \pm 1.04) \mathrm{s}^{-1}$. Reactivity of monoterpenes has weaker seasonality with higher values occurring in the growing season, peaking at $\sim 3 \mathrm{~s}^{-1}$. These values are roughly within the range of previously reported direct measurements of summertime $\mathrm{OH}$ reactivity of $1-21 \mathrm{~s}^{-1}$, where measurements were taken below ponderosa and coniferous forest canopies and within the canopy of a coniferous forest (Ramasamy et al., 2016; Nakashima et al., 2014; Sinha et al., 2010), though at the higher end, likely due to the measurements in this work occurring directly within the canopy. While isoprene dominates reactions with $\mathrm{OH}$ when present (Fig. 5b), mixing ratios of isoprene and detected sesquiterpenes are negligible in the non-growing season, causing a steep decline in reactivity. Due to the year-round presence of monoterpenes, these compounds become the dominant source of $\mathrm{OH}$ reactivity in the non-growing season. Generally, monoterpenes contribute $\sim 100 \%$ in the non-growing season and $\sim 15 \%-35 \%$ of terpene reactivity in the growing season, with isoprene dominating the balance. Detected isoprene oxidation products and sesquiterpenes contribute, on average, $<5 \%$ to $\mathrm{OH}$ reactivity. While some sesquiterpenes may be below level of detection, sesquiterpenes do not generally have $\mathrm{OH}$ reaction rates substantially higher than other more dominant terpenes (Lee et al., 2006) and so are not likely to contribute substantially to $\mathrm{OH}$ reactivity.

\subsubsection{Calculated ozone reactivity}

Calculated $24 \mathrm{~h}$ averaged $\mathrm{O}_{3}$ reactivity ranges between $0.1 \times$ $10^{-5} \mathrm{~s}^{-1}$ and $1.0 \times 10^{-5} \mathrm{~s}^{-1}$ (Fig. 6a) and is almost entirely dominated by monoterpenes (Fig. 6b), even during the growing season peak (monoterpenes: $\sim 70 \%$ ), due to the relatively slow reaction rate of isoprene and its oxidation products with ozone. Ozone reactivity decreases in the non-growing season due to both the decline in isoprene and the decrease in monoterpenes. Average ozone reactivity with isoprene in the growing season is $0.76 \times 10^{-6}( \pm 1.07 \times$ $\left.10^{-6}\right) \mathrm{s}^{-1}$, while in the non-growing season isoprene does not contribute substantially to ozone reactivity (Table 2). Average ozone reactivity with monoterpenes in the growing season is $2.38 \times 10^{-6}\left( \pm 2.41 \times 10^{-6}\right) \mathrm{s}^{-1}$, while in the nongrowing season it is $0.77 \times 10^{-6}\left( \pm 0.79 \times 10^{-6}\right) \mathrm{s}^{-1}$ The measured isoprene oxidation products and sesquiterpenes are not strongly reactive with ozone and therefore have no significant contribution to ozone reactivity. However, unlike with $\mathrm{OH}$ reaction rates, $\mathrm{O}_{3}$ reaction rates of sesquiterpenes are frequently orders of magnitude larger than dominant monoterpenes, so it is possible that low-abundance, highly reactive sesquiterpenes may still contribute non-negligibly to ozone reactivity. Important contributions by low-abundance, highly reactive sesquiterpenes have been previously shown in other environments and cannot be excluded by these measurements (Yee et al., 2018; Ortega et al., 2007; Arnts et al., 2013; Wolfe et al., 2011).

\subsubsection{Calculated nitrate reactivity}

Calculated nitrate reactivity of all detected BVOCs is shown in Fig. 7a in addition to the monthly average reactivity and the reactivity of the monoterpene class. The amount that each BVOC class contributes to nitrate reactivity is shown in Fig. 7b. Nitrate reactivity of observed BVOCs varies seasonally, with a summertime peak in $24 \mathrm{~h}$ averaged reactivity of $\sim 0.4 \mathrm{~s}^{-1}$ driven largely by monoterpenes. Reactivity of monoterpenes has strong seasonality, with higher values occurring in the growing season, peaking at $\sim 0.3-0.4 \mathrm{~s}^{-1}$. As in the case of ozone, nitrate reactivity is dominated by monoterpenes due to the slow reaction rates of isoprene and its oxidation products with $\mathrm{NO}_{3}$. Isoprene contributes between $20 \%-45 \%$ to nitrate reactivity in the growing season 
(a)

\section{November-April}

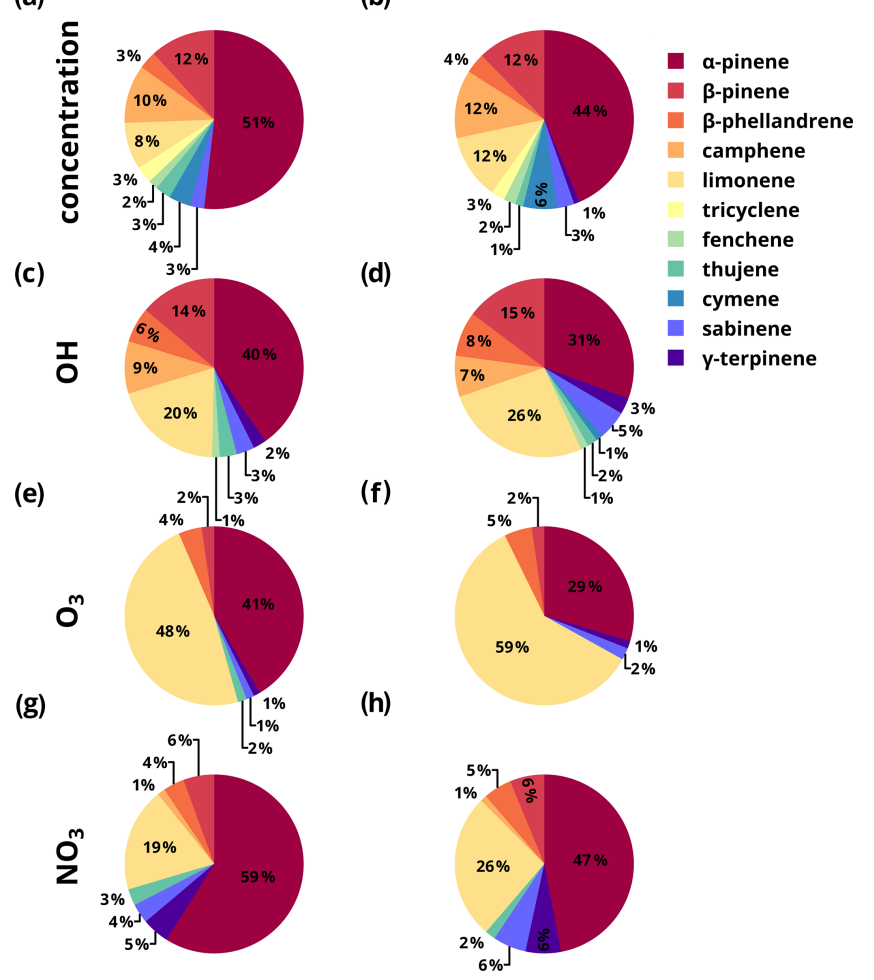

Figure 8. A breakdown of detected monoterpene isomers in the growing and non-growing seasons for $(\mathbf{a}-\mathbf{b})$ concentration, $(\mathbf{c}-\mathbf{d})$ $\mathrm{OH}$ reactivity, (e-f) ozone reactivity, and $(\mathbf{g}-\mathbf{h})$ nitrate reactivity. Values are rounded to the nearest percent, and values below $1 \%$ are not depicted.

and has a mean hourly average of $0.04( \pm 0.05) \mathrm{s}^{-1}$. In the non-growing season, isoprene, like isoprene oxidation products and sesquiterpenes, does not contribute to nitrate reactivity. Monoterpenes dominate nitrate reactivity year-round and have a mean hourly average of $0.10( \pm 0.10) \mathrm{s}^{-1}$ in the growing season and $0.04( \pm 0.04) \mathrm{s}^{-1}$ in the non-growing season. Unmeasured and minimally detected sesquiterpenes are unlikely to contribute substantially to nitrate reactivity as their reaction rates are typically of the same order of magnitude as $\alpha$-pinene and isoprene, but they are present at concentrations 10-100 times lower (Yee et al., 2018).

\subsection{Isomer composition of monoterpenes}

Monoterpenes are detected year-round, but small changes in their compositional breakdown (i.e., the relative contribution of different isomers) lead to important changes in their reactivity and chemistry. Calculated $24 \mathrm{~h}$ average monoterpene mixing ratios ranged between 0.10 and $2.94 \mathrm{ppb}$, with the lowest mixing ratios occurring in the non-growing season daytime and the highest mixing ratios occurring in the growing season nights (as shown in Fig. 4).

Relative contributions from monoterpene isomers are similar for the highest mixing ratio species between the growing and non-growing seasons (Fig. 8a-b). At nearly all times, $\alpha$-pinene contributes the most, followed by $\beta$-pinene, camphene, limonene, and cymene. $\mathrm{OH}$ reactivity (Fig. $8 \mathrm{c}$ and d) of each isomer roughly follows the distribution of mixing ratios, driven by the relatively narrow range in $\mathrm{OH}$ reaction rates for monoterpenes with double bonds (slowest: $\alpha$-pinene $-5.37 \times 10^{-11} \mathrm{~cm}^{3}$ molec $^{-1} \mathrm{~s}^{-1}$, fastest: $\beta$-phellandrene $1.68 \times 10^{-10} \mathrm{~cm}^{3}$ molec. $\left.{ }^{-1} \mathrm{~s}^{-1}\right)$. There is nevertheless some outsize contribution to $\mathrm{OH}$ reactivity by the low-mixing-ratio isomers $\beta$-phellandrene and limonene, which react quickly due to the presence of multiple double bonds and contribute twice as much to reactivity as they do to mixing ratio. Together, these two species account for roughly one-third of $\mathrm{OH}$ reactivity, the abundant but less reactive $\alpha$-pinene accounts for another $\sim$ one-third, and the remaining monoterpenes account for the remainder (mostly $\beta$-pinene, camphene, and $\gamma$-terpinene). The stability of the mixing ratios and $\mathrm{OH}$ reactivity across a year of measurements suggests that the observed distribution of isomers is a reasonable average representation of monoterpenes in this ecosystem. While $\alpha$-pinene is the dominant isomer by far, its lower reaction rate relative to other isomers suggest that it is not necessarily a good representative proxy species for the broader monoterpene compound class. Instead, a more general quantitative description of the rate at which monoterpenes react with $\mathrm{OH}$ (or any other oxidant) would allow a measurement or estimate of bulk monoterpenes to more accurately be converted into an estimate of their impact on reactivity. Correlations between calculated monoterpene oxidant reactivity and detected monoterpene mixing ratio (Fig. S2) suggest a bulk monoterpene reaction rate of $k_{\mathrm{OH}+\mathrm{MT}}=6.9 \times$ $10^{-11} \mathrm{~cm}^{3}$ molec. ${ }^{-1} \mathrm{~s}^{-1}, \sim 30 \%$ greater than the reaction rate of $\alpha$-pinene, and this average rate is relatively temporally stable. It should also be noted that Fig. 8 suggests that $\mathrm{OH}$ reaction with faster reacting, polyunsaturated, lower-mixingratio isomers is as likely as reaction with $\alpha$-pinene.

The role of structure in atmospheric reactions is even more apparent and critical when considering the reactivity of monoterpenes with ozone. Despite its relatively low mixing ratio, limonene is the greatest contributor to reactivity with ozone at $59 \%$ and $48 \%$ in the growing and non-growing season respectively due to an ozone reaction rate 8 times faster than that of the more abundant isomers (Fig. 8e-f). Nearly all the rest of ozone reactivity is contributed by the dominant isomer $\alpha$-pinene (30\% and $41 \%$ ), with a minor contribution from $\beta$-phellandrene $(5 \%$ and $4 \%), \beta$-pinene ( $2 \%$ and $2 \%)$, and $\gamma$-terpinene ( $1 \%$ and $1 \%$ ), while the other isomers are either not reactive with ozone (cymene, tricyclene) or react very slowly with ozone (camphene). Though the general breakdown of ozone reactivity is qualitatively similar during both the growing and non-growing seasons, there are significant quantitative differences. Due to the greater contribution of limonene in 
the growing season compared to the non-growing season, the relative importance of limonene compared to $\alpha$-pinene increases substantially in the growing season, from $1.3: 1$ to $2.1: 1$. In other words, reactions of monoterpenes with ozone, at least in this canopy, are dominated by reactions with limonene, with a smaller but significant contribution from $\alpha$-pinene. The bulk $\mathrm{O}_{3}$ reaction rate with monoterpenes (i.e., the rate that best converts hourly mixing ratio to reactivity) is $k_{\mathrm{O}_{3}+\mathrm{MT}}=1.1 \times 10^{-16} \mathrm{~cm}^{3}$ molec. ${ }^{-1} \mathrm{~s}^{-1}, \sim 25 \%$ faster than $\alpha$-pinene. However, while this average rate is relatively stable across seasons, there are periods in the growing season during which the average reaction rate of monoterpenes is substantially faster, which could have impacts during these periods (Fig. S2). Isomer dependence of nitrate reactivity is somewhere between $\mathrm{O}_{3}$ and $\mathrm{OH}$, with an outsize impact of limonene but with a more even split of reactivity across monoterpenes species. These trends may be explained by the reaction behavior of nitrate. Like the $\mathrm{OH}$ radical, nitrate can react with alkenes by either addition to a double bond or abstract a hydrogen, but it has a stronger tendency to add across a double bond, analogous to $\mathrm{O}_{3}$ (Lee et al., 2014; Pfrang et al., 2006). Similar to $\mathrm{OH}$ reactivity, limonene contributes an outsized amount to $\mathrm{NO}_{3}$ reactivity in both the growing and non-growing season (26\% and $19 \%)$. However, for nitrate reactivity, $\alpha$-pinene remains the dominant component, contributing $48 \%$ to reactions with nitrate in the growing season and $59 \%$ in the non-growing season. The average reaction rate of $\alpha$-pinene is about $\sim 10 \%-20 \%$ faster than the bulk reaction rate of monoterpenes with nitrate radicals (Fig. S2).

\section{Conclusions}

Long-term BVOC measurements are imperative for understanding interannual trends in the formation and loss of ozone and SOA and for improving existing models of BVOC emissions and oxidation. These measurements are difficult, however, without robust measurement techniques that do not require significant maintenance. The use of an automated GC-FID adapted to collect air samples makes it possible to do long-term collection of BVOCs in an unmonitored location. Using this method, we have collected and are continuing to measure a range of BVOCs in the canopy of a forest representative of the Southeastern US, with periodic coupling of a mass spectrometer to allow for identification of the species of interest. The relative ease of this method gives it great potential for additional long-term BVOC monitoring sites to be set up in more locations.

From this study we have gained a greater understanding of the seasonality of BVOCs ranging from isoprene, isoprene oxidation products, monoterpenes, and sesquiterpenes. Isoprene is important for $\mathrm{OH}$ reactivity, but monoterpenes prevail as the most important BVOC class for ozone and nitrate reactivities. Monoterpenes are observed to be a diverse class of BVOCs with 11 identified compounds detected at the site year-round. While $\alpha$-pinene is the most dominant species, a few species with lower mixing ratios but high reactivities (particularly limonene and $\beta$-phellandrene) were found to be important contributors to atmospheric reactivity. This finding is most evident for ozone reactivity but is also the case for $\mathrm{OH}$ and nitrate reactivity. The distribution of monoterpenes is qualitatively stable throughout the year, though some important quantitative differences are observed. Consequently, the distribution measured here may be a useful description of the "typical" monoterpene chemical class observed in mixed, temperate forests. The bulk reaction rates of the monoterpene class with major atmospheric oxidants presented here therefore provide an improved means to estimate the reactions and impacts of monoterpenes in cases where isomerresolved measurements are not available (e.g., when measured using direct-air-sampling mass spectrometers (Davison et al., 2009; Ghirardo et al., 2010)).

Data availability. The integrated GC-FID BVOC data used in this work are available through Mendeley Data. The DOI for this dataset is https://doi.org/10.17632/jx3vn5xxcn.1 (McGlynn and IsaacmanVanWertz, 2021).

Supplement. The supplement related to this article is available online at: https://doi.org/10.5194/acp-21-15755-2021-supplement.

Author contributions. DFM conducted the measurement campaign, completed the data analysis, and led the writing of the manuscript. GIVW supervised the study, designed the measurement campaign, and directed the data analysis and writing of the manuscript. LERB and SEP were instrumental in the upkeep of the measurement site and provided feedback on the manuscript. MTL provided feedback on the manuscript.

Competing interests. Some authors are members of the editorial board of Atmospheric Chemistry and Physics. The peer-review process was guided by an independent editor, and the authors have also no other competing interests to declare.

Disclaimer. Publisher's note: Copernicus Publications remains neutral with regard to jurisdictional claims in published maps and institutional affiliations.

Acknowledgements. This research was funded by the National Science Foundation (AGS 1837882 and AGS 1837891). Tower maintenance and operation were supported in part by the Pace Endowment. Deborah F. McGlynn and Laura E. R. Barry were supported in part by Virginia Space Grant Consortium Graduate Research Fellowships. The authors gratefully acknowledge the assistance of Koong Yi, Graham Frazier, and Bradley Sutliff in their support in the upkeep and maintenance of the instrument at Pace Tower. We thank 
Todd Scanlon for the use of the meteorological data provided in Fig. S1.

Financial support. This research has been supported by the National Science Foundation Division of Atmospheric and Geospace Sciences (grant nos. 1837882 and 1837891) and the Virginia Space Grant Consortium.

Review statement. This paper was edited by Andreas Hofzumahaus and reviewed by two anonymous referees.

\section{References}

Arnts, R. R., Mowry, F. L., and Hampton, G. A.: A highfrequency response relaxed eddy accumulation flux measurement system for sampling short-lived biogenic volatile organic compounds, J. Geophys. Res.-Atmos., 118, 4860-4873, https://doi.org/10.1002/jgrd.50215, 2013.

Atkinson, R. and Arey, J.: Gas-phase tropospheric chemistry of biogenic volatile organic compounds: A review, Atmos. Environ., 37, 197-219, https://doi.org/10.1016/S1352-2310(03)00391-1, 2003.

Atkinson, R., Aschmann, S. M., and Arey, J: Rate constants for the gas-phase reactions of $\mathrm{OH}$ and $\mathrm{NO}_{3}$ radicals and $\mathrm{O}_{3}$ with sabinene and camphene at $296 \pm 2 \mathrm{~K}$, Atmos. Environ. 24, 26472654, https://doi.org/10.1016/0960-1686(90)90144-C, 1990.

Atkinson, R., Aschmann, S. M., Arey, J., and Shorees, B.: Formation of $\mathrm{OH}$ Radicals in the Gas Phase Reactions of $\mathrm{O}_{3}$ With a Series of Terpenes, J. Geophys. Res., 97, 6065-6073, https://doi.org/10.1029/92jd00062, 1992.

Atkinson, R., Baulch, D. L., Cox, R. A., Crowley, J. N., Hampson, R. F., Hynes, R. G., Jenkin, M. E., Rossi, M. J., Troe, J., and IUPAC Subcommittee: Evaluated kinetic and photochemical data for atmospheric chemistry: Volume II - gas phase reactions of organic species, Atmos. Chem. Phys., 6, 3625-4055, https://doi.org/10.5194/acp-6-3625-2006, 2006.

Avnery, S., Mauzerall, D. L., Liu, J., and Horowitz, L. W.: Global crop yield reductions due to surface ozone exposure: 1. Year 2000 crop production losses and economic damage, Atmos. Environ., 45, 2284-2296, https://doi.org/10.1016/j.atmosenv.2010.11.045, 2011a.

Avnery, S., Mauzerall, D. L., Liu, J., and Horowitz, L. W.: Global crop yield reductions due to surface ozone exposure: 2. Year 2030 potential crop production losses and economic damage under two scenarios of $\mathrm{O}_{3}$ pollution, Atmos. Environ., 45, 22972309, https://doi.org/10.1016/j.atmosenv.2011.01.002, 2011 b.

Biesenthal, T. A. and Shepson, P. B.: Observations of anthropogenic inputs of the isoprene oxidation products methyl vinyl ketone and methacrolein to the atmosphere, Geophys. Res. Lett., 24, 13751378, https://doi.org/10.1029/97GL01337, 1997.

Chan, W.: The Fate of Biogenic Hydrocarbons within a Forest Canopy: Field Observation and Model Results, PhD thesis, Department of Environmental Sciences, University of Virginia, USA, https://doi.org/10.18130/V3MV8J, 2011.

Claeys, M., Wang, W., Ion, A. C., and Kourtchev, I.: Formation of secondary organic aerosols from isoprene and its gas-phase oxidation products through reaction with hydrogen peroxide, Atmos. Environ., 38, 4093-4098, https://doi.org/10.1016/j.atmosenv.2004.06.001, 2004.

Corchnoy, S. B. and Atkinson, R.: Kinetics of the Gas-Phase Reactions of $\mathrm{OH}$ and $\mathrm{NO}_{3}$ Radicals with 2-Carene, 1,8-Cineole, p-Cymene, and Terpinolene, Environ. Sci. Technol., 24, 14971502, https://doi.org/10.1021/es00080a007, 1990.

Davison, B., Taipale, R., Langford, B., Misztal, P., Fares, S., Matteucci, G., Loreto, F., Cape, J. N., Rinne, J., and Hewitt, C. N.: Concentrations and fluxes of biogenic volatile organic compounds above a Mediterranean macchia ecosystem in western Italy, Biogeosciences, 6, 1655-1670, https://doi.org/10.5194/bg6-1655-2009, 2009.

Demetillo, M. A. G., Anderson, J. F., Geddes, J. A., Yang, X., Najacht, E. Y., Herrera, S. A., Kabasares, K. M., Kotsakis, A. E., Lerdau, M. T., and Pusede, S. E.: Observing Severe Drought Influences on Ozone Air Pollution in California, Environ. Sci. Technol., 53, 9, 4695-4706, https://doi.org/10.1021/acs.est.8b04852, 2019.

Faiola, C. L., Erickson, M. H., Fricaud, V. L., Jobson, B. T., and VanReken, T. M.: Quantification of biogenic volatile organic compounds with a flame ionization detector using the effective carbon number concept, Atmos. Meas. Tech., 5, 1911-1923, https://doi.org/10.5194/amt-5-1911-2012, 2012.

Faiola, C. L., Buchholz, A., Kari, E., Yli-Pirilä, P., Holopainen, J. K., Kivimäenpää, M., Miettinen, P., Worsnop, D. R., Lehtinen, K. E. J., Guenther, A. B., and Virtanen, A.: Terpene Composition Complexity Controls Secondary Organic Aerosol Yields from Scots Pine Volatile Emissions, Sci. Rep., 8, 1-13, https://doi.org/10.1038/s41598-018-21045-1, 2018.

Faiola, C. L., Pullinen, I., Buchholz, A., Khalaj, F., Ylisirniö, A., Kari, E., Miettinen, P., Holopainen, J. K., Kivimäenpää, M., Schobesberger, S., Yli-Juuti, T., and Virtanen, A.: Secondary Organic Aerosol Formation from Healthy and Aphid-Stressed Scots Pine Emissions, ACS Earth Sp. Chem., 3, 1756-1772, https://doi.org/10.1021/acsearthspacechem.9b00118, 2019.

Fares, S., McKay, M., Holzinger, R., and Goldstein, A. H.: Ozone fluxes in a Pinus ponderosa ecosystem are dominated by non-stomatal processes: Evidence from long-term continuous measurements, Agric. For. Meteorol., 150, 420-431, https://doi.org/10.1016/j.agrformet.2010.01.007, 2010.

Friedman, B. and Farmer, D. K.: SOA and gas phase organic acid yields from the sequential photooxidation of seven monoterpenes, Atmos. Environ., 187, 335-345, https://doi.org/10.1016/j.atmosenv.2018.06.003, 2018.

Fuentes, J., Lerdau, M. T., Atkinson, R., Baldocchi, D., Bottenheim, J. W., Ciccioli, P., Lamb, B., Geron, C., Guenther, A., Sharkey, T. D., and Stockwell, W.: Biogenic Hydrocarbons in the Atmospheric Boundary Layer: A Review, B. Am. Meteorol. Soc., 81, 1537-1576, https://doi.org/10.1175/15200477(2000)081<1537:BHITAB > 2.3.CO;2, 1999.

Gentner, D. R., Isaacman, G., Worton, D. R., Chan, A. W. H., Dallmann, T. R., Davis, L., Liu, S., Day, D. A., Russell, L. M., Wilson, K. R., Weber, R., Guha, A., Harley, R. A., and Goldstein, A. H.: Elucidating secondary organic aerosol from diesel and gasoline vehicles through detailed characterization of organic carbon emissions, Proc. Natl. Acad. Sci., 109, 18318-18323, https://doi.org/10.1073/pnas.1212272109, 2012. 
Geron, C., Rasmussen, R., Arnts, R. R., and Guenther, A.: A review and synthesis of monoterpene speciation from forests in the United States, Atmos. Environ., 34, 1761-1781, https://doi.org/10.1016/S1352-2310(99)00364-7, 2000.

Ghirardo, A., Koch, K., Taipale, R., Zimmer, I., Schnitzler, J.-P., and Rinne, J.: Determination of de novo and pool emissions of terpenes from four common boreal/alpine trees by ${ }^{13} \mathrm{CO}_{2}$ labelling and PTR-MS analysis, Plant. Cell Environ., 33, 781-792, https://doi.org/10.1111/j.1365-3040.2009.02104.x, 2010.

Gilman, J. B., Kuster, W. C., Goldan, P. D., Herndon, S. C., Zahniser, M. S., Tucker, S. C., Brewer, W. A., Lerner, B. M., Williams, E. J., Harley, R. A., Fehsenfeld, F. C., Warneke, C., and De Gouw, J. A.: Measurements of volatile organic compounds during the 2006 TexAQS/GoMACCS campaign: Industrial influences, regional characteristics, and diurnal dependencies of the $\mathrm{OH}$ reactivity, J. Geophys. Res.-Atmos., 114, 1-17, https://doi.org/10.1029/2008JD011525, 2009.

Goldstein, A. H. and Galbally, I.: Known and unexplored organic 115 constituents in the earth's atmosphere, Environ. Sci. Technol., 41, 1515-1521, https://doi.org/10.1021/es072476p, 2007.

Goldstein, A. H., Mckay, M., Kurpius, M. R., Schade, G. W., Lee, A., Holzinger, R., and Rasmussen, R. A.: Forest thinning experiment confirms ozone deposition to forest canopy is dominated by reaction with biogenic VOCs, Geophys. Res. Lett., 31, 2-5, https://doi.org/10.1029/2004GL021259, 2004.

Greenberg, J. P., Guenther, A., Harley, P., Otter, L., Veenendaal, E. M., Hewitt, C. N., James, A. E., and Owen, S. M.: Eddy flux and leaf-level measurements of biogenic VOC emissions from mopane woodland of Botswana, J. Geophys. Res.-Atmos., 108, 1-9, https://doi.org/10.1029/2002jd002317, 2003.

Guenther, A.: Seasonal and spatial variations in natural volatile organic compound emissions, Ecol. Appl., $\quad 7, \quad 34-45, \quad$ https://doi.org/10.1890/10510761(1997)007[0034:SASVIN]2.0.CO;2, 1997.

Guenther, A., Nicholas, C., Fall, R., Klinger, L., Mckay, W. A., and Scholes, B.: A global model of natural volatile organic compound emissions, J. Geophys. Res., 100, 8873-8892, 1995.

Guenther, A., Greenberg, J., Harley, P., Helmig, D., Klinger, L., Vierling, L., Zimmerman, P., and Geron, C.: Leaf, branch, stand and landscape scale measurements of volatile organic compound fluxes from U.S. woodlands, Tree Physiol., 16, 17-24, https://doi.org/10.1093/treephys/16.1-2.17, 1996.

Guenther, A. B., Jiang, X., Heald, C. L., Sakulyanontvittaya, T., Duhl, T., Emmons, L. K., and Wang, X.: The Model of Emissions of Gases and Aerosols from Nature version 2.1 (MEGAN2.1): an extended and updated framework for modeling biogenic emissions, Geosci. Model Dev., 5, 1471-1492, https://doi.org/10.5194/gmd-5-1471-2012, 2012.

Hallquist, M., Wängberg, I., and Ljungström, E.: Atmospheric Fate of Carbonyl Oxidation Products Originating from $\alpha$ Pinene and $\Delta$ 3-Carene: Determination of Rate of Reaction with $\mathrm{OH}$ and $\mathrm{NO}_{3}$ Radicals, UV Absorption Cross Sections, and Vapor Pressures, Environ. Sci. Technol., 31, 3166-3172, https://doi.org/10.1021/es970151a, 1997.

Hatakeyama, S., Isumi, K., Fukuyama, T., and Akimoto, H.: Reactions of ozone with a-Pinene and B-Pinene in air: yields of gaseous and particulate products, J. Geophys. Res.-Atmos., 94, 13013-13024, https://doi.org/10.1029/JD094iD10p13013 1989.
Hellén, H., Praplan, A. P., Tykkä, T., Ylivinkka, I., Vakkari, V., Bäck, J., Petäjä, T., Kulmala, M., and Hakola, H.: Longterm measurements of volatile organic compounds highlight the importance of sesquiterpenes for the atmospheric chemistry of a boreal forest, Atmos. Chem. Phys., 18, 13839-13863, https://doi.org/10.5194/acp-18-13839-2018, 2018.

Helmig, D., Ortega, J., Guenther, A., Herrick, J. D., and Geron, C.: Sesquiterpene emissions from loblolly pine and their potential contribution to biogenic aerosol formation in the Southeastern US, Atmos. Environ., 40, 4150-4157, https://doi.org/10.1016/j.atmosenv.2006.02.035, 2006.

Hoffmann, T., Odum, J. A. Y. R., Bowman, F., Collins, D., Klockow, D., Flagan, R. C., and Seinfeld, J. H.: Formation of Organic Aerosols from the Oxidation of Biogenic Hydrocarbons, J. Atmos. Chem., 1, 189-222, https://doi.org/10.1029/JC084iC08p05083, 1997.

Holdren, M. W. H., Westberg, H. H., and Zimmerman, P. R.: Analysis of Monoterpene Hydrocarbons in Rural Atmospheres, J. Geophys.-Res., 84, 1-6, 1979.

Holopainen, J. K., Virjamo, V., Ghimire, R. P., and Blande, J. D.: Climate Change Effects on Secondary Compounds of Forest Trees in the Northern Hemisphere, Frontiers of Plant Science, 9, 1445, https://doi.org/10.3389/fpls.2018.01445, 2018.

Holzke, C., Hoffmann, T., Jaeger, L., Koppmann, R., and Zimmer, W.: Diurnal and seasonal variation of monoterpene and sesquiterpene emissions from Scots pine (Pinus sylvestris L.), Atmos. Environ., 40, 3174-3185, https://doi.org/10.1016/j.atmosenv.2006.01.039, 2006.

Hunter, J. F., Day, D. A., Palm, B. B., Yatavelli, R. L. N., Chan, A. W. H., Kaser, L., Cappellin, L., Hayes, P. L., Cross, E. S., Carrasquillo, A. J., Campuzano-Jost, P., Stark, H., Zhao, Y., Hohaus, T., Smith, J. N., Hansel, A., Karl, T., Goldstein, A. H., Guenther, A., Worsnop, D. R., Thornton, J. A., Heald, C. L., Jimenez, J. L., and Kroll, J. H.: Comprehensive characterization of atmospheric organic carbon at a forested site, Nat. Geosci., 10, 748753, https://doi.org/10.1038/NGEO3018, 2017.

Intergovernmental Panel on Climate Change (IPCC): Climate Change 2013: The Physical Science Basis, Contribution of Working Group I to the Fifth Assessment Report of the Intergovernmental Panel on Climate Change, edited by: Stocker, T. F., Qin, D., Plattner, G.-K., Tignor, M., Allen, S. K., Boschung, J., Nauels, A., Xia, Y., Bex, V., and Midgley, P. M., Cambridge University Press, Cambridge, United Kingdom and New York, NY, USA, 1535 pp., https://doi.org/10.1017/CBO9781107415324, 2013.

Isaacman-VanWertz, G., Sueper, D. T., Aikin, K. C., Lerner, B. M., Gilman, J. B., de Gouw, J. A., Worsnop, D. R., and Goldstein, A. H.: Automated single-ion peak fitting as an efficient approach for analyzing complex chromatographic data, J. Chromatogr. A., 1529, 81-92, https://doi.org/10.1016/j.chroma.2017.11.005, 2017.

Kalogridis, C., Gros, V., Sarda-Esteve, R., Langford, B., Loubet, B., Bonsang, B., Bonnaire, N., Nemitz, E., Genard, A.-C., Boissard, C., Fernandez, C., Ormeño, E., Baisnée, D., Reiter, I., and Lathière, J.: Concentrations and fluxes of isoprene and oxygenated VOCs at a French Mediterranean oak forest, Atmos. Chem. Phys., 14, 10085-10102, https://doi.org/10.5194/acp-14-10085$2014,2014$. 
Kerdouci, J., Picquet-Varrault, B., and Doussin, J. F.: Prediction of rate constants for gas-phase reactions of nitrate radical with organic compounds: A new structureactivity relationship, Chem. Phys. Chem., 11, 3909-3920, https://doi.org/10.1002/cphc.201000673, 2010.

Kesselmeier, J. and Staudt, M.: An Overview on Emission, Physiology and Ecology.pdf, J. Atmos. Chem., 33, 23-88, https://doi.org/10.1023/A:1006127516791, 1999.

King, M. D., Canosa-Mas, C. E., and Wayne, R. P.: A structureactivity relationship (SAR) for predicting rate constants for the reaction of $\mathrm{NO}_{3}, \mathrm{OH}$ and $\mathrm{O}_{3}$ with monoalkenes and conjugated dienes, Phys. Chem. Chem. Phys., 1, 2239-2246, https://doi.org/10.1039/a901193e, 1999.

Kramer, L. J., Helmig, D., Burkhart, J. F., Stohl, A., Oltmans, S., and Honrath, R. E.: Seasonal variability of atmospheric nitrogen oxides and non-methane hydrocarbons at the GEOSummit station, Greenland, Atmos. Chem. Phys., 15, 6827-6849, https://doi.org/10.5194/acp-15-6827-2015, 2015.

Kroll, J. H. and Seinfeld, J. H.: Chemistry of secondary organic aerosol: Formation and evolution of low-volatility organics in the atmosphere, Atmos. Environ., 42, 3593-3624, https://doi.org/10.1016/j.atmosenv.2008.01.003, 2008.

Kurpius, M. R. and Goldstein, A. H.: Gas-phase chemistry dominates ozone loss to a forest, implying a source of aerosols and hydroxyl radicals to the atmosphere, Geophys. Res. Lett., 30, $2-$ 5, https://doi.org/10.1029/2002GL016785, 2003.

Kwok, E. S. C. and Atkinson, R.: Estimation of hydroxyl radical reaction rate constants for gas-phase organic compounds using a structure-reactivity relationship: An update, Atmos. Environ., 29, 1685-1695, https://doi.org/10.1016/1352-2310(95)00069-B, 1995.

Lamb, B., Guenther, A., Gay, D., and Westberg, H.: A national inventory of biogenic hydrocarbon emissions, Atmos. Environ., 21, 1695-1705, https://doi.org/10.1016/0004-6981(87)90108-9, 1987.

Laothawornkitkul, J., Taylor, J. E., Paul, N. D., and Hewitt, C. N.: Biogenic volatile organic compounds in the Earth system: Tansley review, New Phytol., 183, 27-51, https://doi.org/10.1111/j.1469-8137.2009.02859.x, 2009.

Lee, A., Goldstein, A. H., Keywood, M. D., Gao, S., Varutbangkul, V., Bahreini, R., Ng, N. L., Flagan, R. C., and Seinfeld, J. H.: Gas-phase products and secondary aerosol yields from the ozonolysis of ten different terpenes, 111, 1-18, https://doi.org/10.1029/2005JD006437, 2006.

Lee, L., Teng, A. P., Wennberg, P. O., Crounse, J. D., and Cohen, R. C.: On rates and mechanisms of $\mathrm{OH}$ and $\mathrm{O}_{3}$ reactions with isoprene-derived hydroxy nitrates, J. Phys. Chem. A., 118, 16221637, https://doi.org/10.1021/jp4107603, 2014.

Lerdau, M., Guenther, A., and Monson, R.: Plant Production and Emission of Volatile Organic Compounds, Bioscience, 47, 373383, https://doi.org/10.2307/1313152, 1997.

Lim, S. S., Vos, T., Flaxman, A. D. et al.: A comparative risk assessment of burden of disease and injury attributable to 67 risk factors and risk factor clusters in 21 regions, 1990-2010: A systematic analysis for the Global Burden of Disease Study 2010, Lancet, 380, 2224-2260, https://doi.org/10.1016/S0140-6736(12)617668, 2012.

Ling, Z., He, Z., Wang, Z., Shao, M., and Wang, X.: Sources of methacrolein and methyl vinyl ketone and their con- tributions to methylglyoxal and formaldehyde at a receptor site in Pearl River Delta, J. Environ. Sci., 79, 1-10, https://doi.org/10.1016/j.jes.2018.12.001, 2019.

Matsumoto, J.: Measuring biogenic volatile organic compounds (BVOCs) from vegetation in terms of ozone reactivity, Aerosol Air Qual. Res., 14, 197-206, https://doi.org/10.4209/aaqr.2012.10.0275, 2014.

McGlynn, D. F. and Isaacman-VanWertz, G.: In-Canopy Biogenic Volatile Organic Compounds Mixing Ratios at the Virginia Forest Lab, Mendeley Data [data set], V1, https://doi.org/10.17632/jx3vn5xxcn.1, 2021.

Millet, D. B., Donahue, N. M., Pandis, S. N., Polidori, A., Stanier, C. O., Turpin, B. J., and Goldstein, A. H.: Atmospheric volatile organic compound measurements during the Pittsburgh Air Quality Study: Results, interpretation, and quantification of primary and secondary contributions, J. Geophys. Res.-Atmos., 110, 1-17, https://doi.org/10.1029/2004JD004601, 2005.

Nakashima, Y., Kato, S., Greenberg, J., Harley, P., Karl, T., Turnipseed, A., Apel, E., Guenther, A., Smith, J., and Kajii, Y.: Total $\mathrm{OH}$ reactivity measurements in ambient air in a southern Rocky mountain ponderosa pine forest during BEACHON-SRM08 summer campaign, Atmos. Environ., 85, 18, https://doi.org/10.1016/j.atmosenv.2013.11.042, 2014.

NIST Chemical Kinetics Database: https://kinetics.nist.gov/ kinetics/index.jsp, last access: 5 May 2020.

Ortega, J., Helmig, D., Guenther, A., Harley, P., Pressley, S., and Vogel, C.: Flux estimates and $\mathrm{OH}$ reaction potential of reactive biogenic volatile organic compounds (BVOCs) from a mixed northern hardwood forest, 41, 5479-5495, https://doi.org/10.1016/j.atmosenv.2006.12.033, 2007.

Panopoulou, A., Liakakou, E., Sauvage, S., Gros, V., Locoge, N., Stavroulas, I., Bonsang, B., Gerasopoulos, E., and Mihalopoulos, N.: Yearlong measurements of monoterpenes and isoprene in a Mediterranean city (Athens): Natural vs anthropogenic origin, Atmos. Environ., 243, 117803, https://doi.org/10.1016/j.atmosenv.2020.117803, 2020.

Park, C., Schade, G. W., and Boedeker, I.: Flux measurements of volatile organic compounds by the relaxed eddy accumulation method combined with a GC-FID system in urban Houston, Texas, Atmos. Environ., 44, 2605-2614, https://doi.org/10.1016/j.atmosenv.2010.04.016, 2010.

Peake, E. and Sandhu, H. S.: The formation of ozone and peroxyacetyl nitrate (PAN) in the urban atmospheres of Alberta, Canadian Journal of Chemistry, 61, 5, 927-935, https://doi.org/10.1139/v83-166, 1983.

Pfrang, C., King, M. D., Canosa-Mas, C. E., and Wayne, R. P.: Structure-activity relations (SARs) for gas-phase reactions of $\mathrm{NO}_{3}, \mathrm{OH}$ and $\mathrm{O}_{3}$ with alkenes: An update, Atmos. Environ., 40, 1180-1186, https://doi.org/10.1016/j.atmosenv.2005.09.080, 2006.

Pinto, D. M., Tiiva, P., Miettinen, P., Joutsensaari, J., Kokkola, H., Nerg, A.-M., Laaksonen, A., and Holopainen, J. K.: The effects of increasing atmospheric ozone on biogenic monoterpene profiles and the formation of secondary aerosols, Atmos. Environ., 41, 4877-4887, https://doi.org/10.1016/j.atmosenv.2007.02.006, 2007.

Plass-Dülmer, C., Michl, K., Ruf, R., and Berresheim, H.: C2C8 Hydrocarbon measurement and quality control procedures at the Global Atmosphere Watch Observatory Hohenpeissenberg, 
J. Chromatogr. A, 953, 175-197, https://doi.org/10.1016/S00219673(02)00128-0, 2002.

Pollmann, J., Ortega, J., and Helmig, D.: Analysis of atmospheric sesquiterpenes: Sampling losses and mitigation of ozone interferences, Environ. Sci. Technol., 39, 9620-9629, https://doi.org/10.1021/es050440w, 2005.

Porter, W. C., Safieddine, S. A., and Heald, C. L.: Impact of aromatics and monoterpenes on simulated tropospheric ozone and total OH reactivity, Atmos. Environ., 169, 250-257, https://doi.org/10.1016/j.atmosenv.2017.08.048, 2017.

Pratt, K. A., Mielke, L. H., Shepson, P. B., Bryan, A. M., Steiner, A. L., Ortega, J., Daly, R., Helmig, D., Vogel, C. S., Griffith, S., Dusanter, S., Stevens, P. S., and Alaghmand, M.: Contributions of individual reactive biogenic volatile organic compounds to organic nitrates above a mixed forest, Atmos. Chem. Phys., 12, 10125-10143, https://doi.org/10.5194/acp-12-101252012, 2012.

Pusede, S. E., Gentner, D. R., Wooldridge, P. J., Browne, E. C., Rollins, A. W., Min, K.-E., Russell, A. R., Thomas, J., Zhang, L., Brune, W. H., Henry, S. B., DiGangi, J. P., Keutsch, F. N., Harrold, S. A., Thornton, J. A., Beaver, M. R., St. Clair, J. M., Wennberg, P. O., Sanders, J., Ren, X., VandenBoer, T. C., Markovic, M. Z., Guha, A., Weber, R., Goldstein, A. H., and Cohen, R. C.: On the temperature dependence of organic reactivity, nitrogen oxides, ozone production, and the impact of emission controls in San Joaquin Valley, California, Atmos. Chem. Phys., 14, 3373-3395, https://doi.org/10.5194/acp-143373-2014, 2014.

Ramasamy, S., Ida, A., Jones, C., and Kato, S.: Total OH reactivity measurement in a BVOC dominated temperate forest during a summer campaign, 2014, Atmos. Environ., 131, 41-54, https://doi.org/10.1016/j.atmosenv.2016.01.039, 2016.

Read, K. A., Lee, J. D., Lewis, A. C., Moller, S. J., Mendes, L., and Carpenter, L. J.: Intra-annual cycles of NMVOC in the tropical marine boundary layer and their use for interpreting seasonal variability in CO, J. Geophys. Res.-Atmos., 114, 1-14, https://doi.org/10.1029/2009JD011879, 2009.

Sadiq, M., Tai, A. P. K., Lombardozzi, D., and Val Martin, M.: Effects of ozone-vegetation coupling on surface ozone air quality via biogeochemical and meteorological feedbacks, Atmos. Chem. Phys., 17, 3055-3066, https://doi.org/10.5194/acp-173055-2017, 2017.

Scanlon, J. and Willis, D.: Calculation of Flame Ionization Detector Relative Response Factors Using the Effective Carbon Number Concept, J. Chromatogr. Sci., 23, 333-340, https://doi.org/10.1093/chromsci/23.8.333, 1985.

Schade, G. W. and Goldstein, A. H.: Fluxes of oxygenated volatile organic compounds from a ponderosa pine plantation, J. Geophys. Res.-Atmos., 106, 3111-3123, https://doi.org/10.1029/2000JD900592, 2001.

Schade, G. W. and Goldstein, A. H.: Increase of monoterpene emissions from a pine plantation as a result of mechanical disturbances, Geophys. Res. Lett., 30, 10-13, https://doi.org/10.1029/2002GL016138, 2003.

Schade, G. W., Goldstein, A. H., and Lamanna, M. S.: Are Monoterpene Emissions influenced by Humidity?, Geophys. Res. Lett., 26, 2187-2190, https://doi.org/10.1029/1999GL900444, 1999.

Shu, Y. and Atkinson, R.: Rate constants for the gas-phase reactions of $\mathrm{O}_{3}$ with a series of Terpenes and $\mathrm{OH}$ radical formation from the $\mathrm{O}_{3}$ reactions with Sesquiterpenes at $296 \pm 2 \mathrm{~K}$, Int. J. Chem. Kinet., 26, 1193-1205, https://doi.org/10.1002/kin.550261207, 1994.

Simpson, I. J., Andersen, M. P. S., Meinardi, S., Bruhwiler, L., Blake, N. J., Helmig, D., Sherwood Rowland, F., and Blake, D. R.: Long-term decline of global atmospheric ethane concentrations and implications for methane, Nature, 488, 490-494, https://doi.org/10.1038/nature11342, 2012.

Sinha, V., Williams, J., Lelieveld, J., Ruuskanen, T. M., Kajos, M. K., Patokoski, J., Hellen, H., Hakola, H., Mogensen, D., Boy, M., Rinne, J., and Kulmala, M.: OH reactivity measurements within a boreal forest: Evidence for unknown reactive emissions, Environ. Sci. Technol., 44, 6614-6620, https://doi.org/10.1021/es101780b, 2010.

Stein, S. E. and Scott, D. R.: ScienceDirect - Journal of the American Society for Mass Spectrometry: Optimization and testing of mass spectral library search algorithms for compound identification, J. Am. Soc. Mass Spectrom., 5, 859-866, 1994.

Trainer, M., Parrish, D. D., Norton, R. B., Fehsenfeld, F. C., Anlauf, K. G., Bottenheim, J. W., Tang, Y. Z., Wiebe, H. A., Roberts, J. M., Tanner, R. L., Newman, L., Bowersox, V. C., Meagher, J. F., Olszyna, K. J., Rodgers, M. O., Wang, T., Berresheim, H., Demerjian, K. L., and Roychowdhury, U. K.: Correlation of ozone with $\mathrm{NO}_{y}$ in photochemically aged air, J. Geophys. Res.-Atmos., 98, 2917-2925, https://doi.org/10.1029/92JD01910, 1993.

US Environmental Protection Agency: Estimation Programs Interface Suite ${ }^{\mathrm{TM}}$ for Microsoft ${ }^{\circledR}$ Windows, v 4.11, available at: https://www.epa.gov/tsca-screening-tools/ epi-suitetm-estimation-program-interface (last access: 3 January 2021), 2012.

Wolfe, G. M., Thornton, J. A., McKay, M., and Goldstein, A. H.: Forest-atmosphere exchange of ozone: sensitivity to very reactive biogenic VOC emissions and implications for incanopy photochemistry, Atmos. Chem. Phys., 11, 7875-7891, https://doi.org/10.5194/acp-11-7875-2011, 2011.

Worton, D. R., Decker, M., Isaacman-VanWertz, G., Chan, A. W. H., Wilson, K. R., and Goldstein, A. H.: Improved molecular level identification of organic compounds using comprehensive two-dimensional chromatography, dual ionization energies and high resolution mass spectrometry, Analyst, 142, 2395-2403, https://doi.org/10.1039/c7an00625j, 2017.

Yáñez-Serrano, A. M., Nölscher, A. C., Bourtsoukidis, E., Gomes Alves, E., Ganzeveld, L., Bonn, B., Wolff, S., Sa, M., Yamasoe, M., Williams, J., Andreae, M. O., and Kesselmeier, J.: Monoterpene chemical speciation in a tropical rainforest:variation with season, height, and time of dayat the Amazon Tall Tower Observatory (ATTO), Atmos. Chem. Phys., 18, 3403-3418, https://doi.org/10.5194/acp-18-3403-2018, 2018.

Yee, L. D., Isaacman-VanWertz, G., Wernis, R. A., Meng, M., Rivera, V., Kreisberg, N. M., Hering, S. V., Bering, M. S., Glasius, M., Upshur, M. A., Gray Bé, A., Thomson, R. J., Geiger, F. M., Offenberg, J. H., Lewandowski, M., Kourtchev, I., Kalberer, M., de Sá, S., Martin, S. T., Alexander, M. L., Palm, B. B., Hu, W., Campuzano-Jost, P., Day, D. A., Jimenez, J. L., Liu, Y., McKinney, K. A., Artaxo, P., Viegas, J., Manzi, A., Oliveira, M. B., de Souza, R., Machado, L. A. T., Longo, K., and Goldstein, A. H.: Observations of sesquiterpenes and their oxidation products in central Amazonia during the wet and dry seasons, Atmos. Chem. 
Phys., 18, 10433-10457, https://doi.org/10.5194/acp-18-104332018, 2018.

Zheng, Y., Unger, N., Tadi, J. M., Seco, R., Guenther, A. B., Barkley, M. P., Potosnak, M. J., Murray, L. T., Michalak, A. M., Qiu, X., Kim, S., Karl, T., Gu, L., and Pallardy, S. G.: Drought impacts on photosynthesis, isoprene emission and atmospheric formaldehyde in a mid-latitude forest, Atmos. Environ., 167, 190-201, https://doi.org/10.1016/j.atmosenv.2017.08.017, 2017.
Zimmerman, P. R.: Testing of hydrocarbones emissions from vegetation, leaf litter and aquatic surfaces, and development of a methodology for compiling biogenic emissions inventories, Epa450/4-79-004, 1-112 pp., 1979. 